\title{
ANTECEDENTES FILOSÓFICOS E TEOLÓGICOS DO CONCEITO PASCALIANO DE NATUREZA HUMANA
}

\author{
Luís C. G. Oliva* \\ lcoliva@uol.com.br
}

RESUMO $O$ artigo pretende examinar os antecedentes do conceito pascaliano de natureza humana, desde a matriz aristotélica da idéia de natureza, passando pela absorção do conceito pelo pensamento cristão de Agostinho e Tomás, pela constituição do conceito teológico de pura natureza na escolástica tardia e sua crítica por Jansenius. Pascal aprofunda essa crítica, mostrando que a completude e a suficiência pressupostas na idéia de pura natureza são incompatíveis com a atual condição do homem, embora a infelicidade humana aponte para o fato de que a natureza humana permanece relevante como uma exigência irrealizável.

Palavras-chave Pascal; Natureza Humana; Pura natureza; Incompletude

ABSTRACT The paper intends to examine the antecedents of the Pascalian concept of human nature, from the Aristotelian matrix of the idea of nature, going through the Christian absorption of this concept in Augustine and Thomas, to the elaboration of the theological concept of pure nature in Late Scholastics and its critic by Jansenius. Pascal deepens this criticism, 
showing that the completeness and sufficiency presupposed in the idea of pure nature are incompatible with the present human condition, though human unhappiness points to the fact that human nature remains relevant as an nonachievable demand.

Keywords Pascal; Human Nature; Pure Nature; Incompleteness

Segundo Bernard Tocanne, o termo physis, ou natureza, encontra-se já na língua homérica, ligando-se, de um lado, à idéia de nascimento ou crescimento aplicada a plantas ou produções cujo desenvolvimento lembra o de um vegetal. O ponto de partida, portanto, é a imagem de um ser vivo que se desenvolve espontaneamente. De outro lado, o termo liga-se ao estado ou produto final desse crescimento espontâneo.

(...) physis designa por vezes, na língua arcaica, o nascimento, a geração, ou então o resultado do nascimento, a progenitura, ou ainda o resultado do crescimento, o tamanho, a estatura, ou bem o aspecto exterior e sensível de um ser. Por sua etimologia, a idéia de natureza é já ambivalente, encerrando a imagem de um movimento, de um processo interno e espontâneo de desenvolvimento, estreitamente associado à geração do ser vivo, ou então à imagem de uma estabilidade e de um produto acabado e consistente. ${ }^{1}$

Ainda segundo Tocanne, o termo se difunde amplamente a partir do século $\mathrm{V}$, assumindo uma pluralidade de significados, organizados, contudo, em torno de três grandes valores: 1) um valor ativo e dinâmico, ligado à imagem da geração e do crescimento, apontando para as idéias de espontaneidade e inatidade; 2) um valor estático, ligado à idéia de permanência diante do devir fenomênico; 3) finalmente, um valor normativo, já que o processo de geração e crescimento se dirige a um fim determinado. Ora, esses três valores estão presentes já na apresentação aristotélica do conceito de natureza.

Logo no início do livro II da Física, Aristóteles destaca o caráter ativo e espontâneo dos seres naturais, opondo natureza e arte. Os animais, as plantas e os corpos simples (terra, fogo, água e ar) são da natureza; em contraste com uma cama ou uma peça de roupa, que são produtos da arte. Os primeiros distinguem-se por possuírem, em si mesmos, um princípio de movimento e 
parada, seja quanto ao lugar, ao crescimento ou à alteração. Já a cama não tem nenhuma tendência natural à mudança, a não ser na medida em que, acidentalmente, é feita de madeira. Nessa medida, poderá apodrecer ou mesmo brotar, mas não enquanto é cama, produto da arte, e sim enquanto, por ser de madeira, tem uma natureza. "Pois a natureza é um princípio e uma causa de movimento e de repouso para a coisa na qual reside imediatamente, por essência, e não por acidente." "2 Enquanto cama, o referido objeto não tem uma natureza, já que o princípio de sua fabricação está fora dela, no artesão que a construiu. Daí que a natureza deva ser vista como um princípio de atividade não apenas não acidental, mas também imanente.

Mas o que são esses seres que têm uma natureza? E aqui já passamos ao segundo aspecto destacado por Tocanne. Diz Aristóteles: "Ora, todas estas coisas são substâncias, pois são sujeitos e a natureza está sempre em um sujeito." ${ }^{3} \mathrm{O}$ caráter substancial dos seres naturais é um elemento fundamental da concepção aristotélica. No capítulo 2 das Categorias, diz Aristóteles:

Quando usamos palavras sem as combinar podemos predicar algo de um sujeito, ainda que não se achem presentes em nenhum sujeito, por exemplo: podemos predicar homem deste ou daquele homem, mas homem não se acha em nenhum sujeito. Outras estão em um sujeito, embora não possam ser predicadas de qualquer sujeito (por "em um sujeito" entendo o que, não se achando em um sujeito como as partes se acham no todo, não pode contudo ser independentemente do sujeito em que é). Por exemplo, algum saber gramatical existe em um sujeito, a saber, na mente, mas não se pode dizer de nenhum sujeito; e uma certa brancura existe em um sujeito, por exemplo no corpo, pois toda cor é em um corpo, mas não pode afirmar-se de qualquer sujeito. Há também outras coisas que se afirmam simultaneamente de um sujeito e em um sujeito, por exemplo: o saber é em um sujeito, a mente, e, por outro lado, afirma-se também de um sujeito, a gramática. Há por fim outras que não são nem em um sujeito, nem predicadas de qualquer sujeito, por exemplo este homem, este cavalo, pois nenhuma destas coisas se acha em um sujeito, nem pode ser predicada a um sujeito. ${ }^{4}$

Donde decorre que Aristóteles possa definir a substância, no capítulo 5, como aquilo que nunca se predica de um sujeito, nem em um sujeito, por exemplo, "este homem" ou "este cavalo". Como sujeito de predicados, a substância pode mudar, encaminhar-se de um estado a outro, atualizar suas potencialidades, permanecendo, contudo, idêntica. Por isso, dirá Aristóteles, "a principal propriedade da substância parece ser isto: que, apesar de permanecer

2 ARISTÓTELES, 1961, p. 58.

3 Ibidem, p. 60.

4 ARISTÓTELES, 1985, p. 44. 
idêntica, uma, e a mesma, é capaz de receber qualificações contrárias". 5 A natureza é um princípio imanente de aquisição de predicados; princípio, portanto, indissociável da substância que os suporta. Mas não de quaisquer predicados, e sim apenas daqueles conformes à respectiva natureza, a saber, os atributos essenciais. Diz Aristóteles, "por exemplo, para o fogo o transporte para o alto; pois isto não é natureza, não tem uma natureza, mas isto é por natureza e conforme à natureza". ${ }^{6}$

É com estes pressupostos, o caráter de princípio de movimento e a vinculação com a substância, que Aristóteles empreenderá a complexa discussão visando a definir a natureza como matéria ou como forma. Por um lado, é a matéria, o sujeito imediato e informe de cada coisa natural, que permanece sob as mudanças, garantindo a identidade da substância. Por outro lado, a matéria é pura potencialidade, enquanto a forma é o ato da coisa. Não se pode dizer que algo é conforme à arte ou conforme à natureza quando tratamos da pura potência. Se a permanência do sujeito é dada pela matéria, a naturalidade dele não pode dispensar a forma, que o atualiza segundo seu princípio interno. Sendo assim, a palavra natureza deve ser entendida nos dois sentidos: forma e matéria, ambos objetos do estudioso da natureza; mas, sobretudo, no de forma.

Resta ainda o último aspecto destacado por Tocanne, ao qual Aristóteles dedica todo o capítulo oito do livro II: a finalidade contida na natureza. A esta altura do livro, o autor já expôs sua doutrina das quatro causas e mostrou que só de posse desse conhecimento o físico poderá ter a ciência da natureza, mas é preciso antes de tudo refutar a objeção de que a natureza não seria uma das coisas que agem em vista de um fim:

O que impede a natureza de agir, não em vista de um fim nem porque é o melhor, mas como Zeus faz chover, não para aumentar a colheita, mas por necessidade? Pois a evaporação, tendo-se elevado, deve resfriar-se e, tendo esfriado e virado água, deve descer; quanto ao crescimento da plantação que segue o fenômeno, é um acidente. ${ }^{7}$

São vários os argumentos que Aristóteles apresenta para defender a finalidade contra o puro mecanicismo. O que nos importa, no entanto, é aquilo que se deixa perceber por entre os argumentos: a causa final é constitutiva da própria idéia de natureza. Não há um princípio de movimento e repouso sem 
o fim, que representa o acabamento perfeito desse ser em movimento. Diz Aristóteles:

E uma tal tese (a necessidade mecânica) suprime, de modo geral, as coisas naturais e a natureza; com efeito, são coisas naturais todas aquelas que, movidas de uma maneira contínua por um princípio interior, chegam a um fim; de cada um destes princípios deriva um termo final diferente para cada uma e que não é ao sabor da fortuna; e este termo é constante para cada coisa a não ser que haja impedimentos. ${ }^{8}$

Desse modo, a exclusão da finalidade seria a exclusão da própria natureza, diluindo completamente a distinção entre o natural (que é por essência) e o fortuito (acidental).

\section{O Cristianismo e Santo Agostinho}

A idéia de natureza sofrerá importantes transformações ao introduzir-se, no século II, no pensamento cristão nascente. A concepção cristã de natureza sobrepõe-se à helênica, colocando a exigência teológica de purificar o tema de seus elementos incompatíveis com os dados da fé. Agora é preciso distinguir radicalmente a Natura creatrix e a Natura creata, Deus e sua obra, garantindo, de um lado, a transcendência divina e, de outro, a realidade própria do criado. No século IV, o pensamento de Santo Agostinho trouxe um novo ponto de vista para a questão, opondo a natureza não mais apenas ao artificial, como em Aristóteles, mas à graça.

É justamente através da discussão empreendida em torno da graça que compreenderemos melhor o que é a natureza (no caso, a natureza humana) em Agostinho. Antes de mais nada, é preciso lembrar que o deus agostiniano, sendo o Soberano Bem, se basta. Não precisa de nada para além de si mesmo e, portanto, nada precisa dar ou criar. Se o faz, é livremente, gratuitamente, de modo que, em sentido lato, toda a sua obra é graça. Como diz Gilson:

\footnotetext{
Para ser, o homem não teve que merecê-lo, pois, para merecer, ter-lhe-ia sido preciso primeiro ser; ora, não sendo, contudo ele foi feito, e não somente feito como uma pedra ou um animal, mas feito à imagem de seu criador. Neste sentido impróprio, a própria natureza seria uma graça, mas uma graça por assim dizer universal e comum a todos. ${ }^{9}$
} 
Entretanto, como bem destaca Gilson, trata-se de um sentido impróprio de graça. A verdadeira graça não é aquela pela qual fomos criados, mas aquela pela qual recebemos o dom da perseverança na fé: "Além daquela graça, pela qual é criada a natureza humana (esta, com efeito, é comum aos cristãos e aos pagãos), há uma graça maior, não aquela pela qual somos criados homens pelo Verbo, mas pela qual somos feitos fiéis pelo Verbo feito carne." ${ }^{10}$ É desse "acréscimo" que distingue cristãos e pagãos que fala Agostinho ao referir-se à graça. Isso não impediria, por outro lado, que Deus tivesse dado ao homem ou a qualquer criatura uma natureza diversa da que tem atualmente, fosse ela melhor ou pior. Não haveria nada de indigno para Deus em fazê-lo, visto que o ato criador é totalmente livre. Daí que o que é graça hoje poderia ser natureza se a criação tivesse sido outra.

É essa discussão dos limites de natureza e graça que empreende Agostinho em seus escritos antipelagianos. Para o filósofo, o ardil de Pelágio é afirmar que está discutindo a possibilidade das coisas, não sua existência efetiva, de modo que, ao ser contradito pelas Escrituras, considera-se imune, já que elas falam do que é, não do que apenas poderia ser. Por outro lado, as certezas obtidas a respeito das possibilidades ou impossibilidades devem impor-se às coisas. Daí às heresias, os passos são poucos. Diz Pelágio (citado por Agostinho): "Torno a repeti-lo: Eu digo que o homem pode viver sem pecado. O que tu dizes? Que o homem não pode viver sem pecado? Eu não digo que o homem pode viver sem pecado nem tu o dizes. Discutimos sobre a possibilidade ou não possibilidade; não discutimos sobre a realidade ou não-realidade." ${ }^{11}$ Para Pelágio, os contra-exemplos bíblicos não anulam a possibilidade de não pecar, do contrário não haveria culpa. E diante da objeção de que isso só é possível pela graça de Deus, Pelágio não hesita em responder que tal afirmação apenas comprova sua tese, afinal "a melhor demonstração da possibilidade de uma coisa é a formulação de suas condições, pois a qualidade exige um suporte real". ${ }^{12}$

Para Pelágio, se o homem tem a possibilidade de não pecar inscrita em sua natureza, o meio utilizado para alcançá-lo, seja a graça, seja o puro livrearbítrio humano, é parte integrante dessa propriedade. Agostinho percebe muito bem que essa operação faz que a graça divina seja absorvida na natureza e, em última análise, o livre-arbítrio humano, também parte da natureza, será o responsável pela salvação. E como Pelágio responderia à acusação de que

10 GILSON, 1987, p. 192.

11 AGOSTINHO, 1999, p. 118.

12 Ibidem, p. 120. 
esvazia o papel da graça divina? "Quando se diz que o homem é capaz, não o atribuímos ao livre-arbítrio, contudo ao autor da natureza, ou seja, Deus. Haverá alguém que entenda que se possa conseguir sem a graça de Deus o que se considera pertencer propriamente a Deus?"13 A vontade de pecar ou não pecar, como a vontade de falar ou não falar, pertencem a mim, mas a capacidade para não pecar e não falar é dada por Deus na natureza. Não depende de mim não poder falar, e sim de Deus, que me deu os órgãos da fala, com os quais eu decido falar ou não. Como o não pecar é submetido ao poder não pecar, que de possibilidade lógica passou sutilmente a capacidade humana, e poder não pecar vem diretamente de Deus, devemos atribuir nossa salvação a Deus, ainda que nosso livre-arbítrio seja o fator determinante para ela.

Santo Agostinho não pode deixar de denunciar esta armadilha pelagiana:

Com aquelas sentenças atribui à graça de Deus a possibilidade de não pecar, porque Deus é o autor da natureza, à qual ele declara inserida de modo inseparável a possibilidade de não pecar. Portanto, quando o homem quer, faz; porque não quer, não faz. Existindo esta possibilidade inseparável, não é possível pensar em debilidade da vontade, ou antes, em cooperação da vontade e em carência de perfeição ${ }^{14}$

O que Pelágio consegue, com isso, é impossibilitar a idéia de natureza humana corrompida. Qualquer que fosse a natureza humana, Deus seria bom ao criá-la, pois nada lhe deve. No entanto, não se poderia aceitar uma natureza humana decaída em relação a suas próprias possibilidades, ou estas deixariam de existir e, com elas, a responsabilidade moral. Fazendo da graça parte da natureza, Pelágio faz com que uma não possa desvincular-se da outra sem contradição. De sua parte, Agostinho acredita no poder corrosivo do pecado original, por isso não pode aceitar a incorporação natureza/graça ou, se quisermos, natureza/possibilidade de realização desta mesma natureza.

Todo esforço de Agostinho no A natureza e a graça é mostrar que Pelágio, ao elevar o poder da natureza humana, desconsidera que estamos diante de uma natureza corrompida, doente, diversa da situação em que foi criada. Essa natureza deve ser curada para alcançar o seu fim. De que adianta dizer, como Pelágio, que a possibilidade de andar pertence à natureza humana se o homem tiver as pernas quebradas? Dada a diferença de estados, a possibilidade de realização da natureza encontra-se muito afastada dela mesma. 
Santo Agostinho assume, já em Do livre arbitrio, uma duplicidade na noção de natureza humana, ou pelo menos a existência de dois estados historicamente delimitados da natureza humana.

(...) do mesmo modo, uma coisa entendemos pela palavra natureza quando falamos em sentido próprio, ou seja, quando falamos da natureza humana que Deus deu ao homem quando o criou no estado de inocência, e outra quando falamos desta em que, como conseqüência do pecado original, nascemos sujeitos à morte, ignorantes e escravos da concupiscência, estado do qual fala o Apóstolo: Temos sido, como os demais, filhos da ira por natureza. ${ }^{15}$

A concepção de Pelágio, por sua vez, parece muito mais próxima da concepção aristotélica de natureza. A natureza humana pelagiana é sim um princípio de movimento que constitui substâncias tendentes a um fim. Os meios para realizar esse fim estão também nele contidos, garantindo ao conceito de natureza um elemento de completude, o qual podemos extrair de outro texto aristotélico que será importante para toda a tradição cristã, o livro II do De caelo: "Se a natureza tivesse dado ao céu uma inclinação ao movimento progressivo, teria dado também os instrumentos para tal movimento", ${ }_{16}^{16} \mathrm{de}$ onde se extrai o axioma "o desejo natural não pode ser vão, já que a natureza nada faz em vão". É essa completude de princípio, fim e meios que a natureza agostiniana não pode oferecer. E não se trata apenas de um problema posterior à queda de Adão. Ao criticar Pelágio, Agostinho diz:

Se falasse do homem ainda dotado de natureza íntegra e pura, de que agora estamos privados (...), se falasse com essa ressalva, repito, mesmo assim não seria correto afirmar que não pecar depende somente de nós, embora o ato de pecado seja nosso. Pois, nesse caso, teríamos a ajuda de Deus a se oferecer aos de boa vontade, como a luz se apresenta nos olhos sãos possibilitando a visão com sua ajuda. ${ }^{17}$

Mesmo Adão precisava de uma graça que transcendia sua própria natureza. Porém, precisamente enquanto sobrenatural, a graça complementa e realiza a natureza. Como diz Henri de Lubac, "entre a natureza e a graça não se tratava, para Agostinho, de oposição, mas de inclusão; não de luta, mas de união. Não se tratava para o homem de aniquilamento, mas de unificação íntima e de transformação". ${ }^{18}$ 
E o que seria a natureza pura, sem a corrupção do pecado e sem o auxílio da graça? Que tipo de realização o conceito de natureza, por si mesmo, garantiria ao homem agostiniano? Sobre isso, Agostinho silencia: "Não se encontra em Agostinho, ao que eu saiba, definição do que a essência metafísica do homem pode ter implicado como pertencente de direito a sua natureza; o ponto de vista em que ele se situa constantemente é de certo modo histórico e puramente de fato." 19 Vamos então aos estados históricos da natureza humana.

Se formos de novo ao Do livre arbitrio, texto que combate o maniqueísmo, veremos que Santo Agostinho faz questão de destacar que a corrupção da natureza humana não significa que esta perca totalmente a bondade. Se, contra Pelágio, Agostinho afirmará que o mal contaminou, sim, as capacidades da natureza humana, aqui deve ressaltar que ela mantém o caráter de substância, sem o que não há natureza, bem como sua positividade. Afinal, aquilo que é menos bom do que já foi continua sendo bom. Se a corrupção o privasse de todo o bem, tornar-se-ia incorruptível, ou seja, uma criatura tornar-se-ia superior (porque incorruptível) por meio de sua própria depravação, o que é um absurdo manifesto. Daí que a própria duplicidade da natureza humana perderia o sentido caso o estado atual fosse exclusivamente maligno.

Por isso se diz com razão que toda natureza, enquanto é natureza, é boa; porque, se é incorruptível, é melhor que a corruptível, e se é corruptível, é certamente boa porque ao corromper-se faz-se pior. Toda natureza ou é corruptível ou incorruptível, logo toda natureza é boa. Entendo por natureza aquilo a que podemos dar o nome de substância. Portanto toda substância ou é Deus ou provém de Deus, porque todo bem ou é Deus ou provém de Deus (grifos nossos). ${ }^{20}$

A natureza, como primeiro dom de Deus, enquanto criador, ao homem, não pode ser ruim. É um dos primeiros princípios assumidos por Agostinho que de Deus só provenham o bem e a justiça. Não poderia, portanto, conceber uma natureza totalmente maléfica oriunda de Deus. E muito menos poderia conceber uma natureza positivamente má oriunda de um princípio maligno oposto a Deus, sob o risco de ver-se recair no maniqueísmo.

Agostinho pode, isto sim, ver a natureza humana de um duplo aspecto: primeiro como uma substância boa e incorrupta, embora não incorruptível, como foi a de Adão; depois como uma substância boa, mas corrompida por acidentes ruins, os quais, embora acidentes, podem condená-la à morte eterna. Essa segunda, diminuída e viciosa, é a que vemos hoje e que surgiu com o 
pecado original. No entanto, a verdadeira natureza humana, o verdadeiro homem à imagem de Deus, é o que foi criado em Adão. "Assim pois chamamos vício àquilo que vemos de falta na perfeição da natureza, manifestando com isso louvor àquela natureza cuja imperfeição vituperamos, precisamente porque desejaríamos que fosse perfeita." ${ }^{21} \mathrm{~A}$ falta dos chamados dons preternaturais, que não temos hoje, mas permitiam a Adão conseguir a salvação eterna e viver num paraíso agradável junto a Deus, é o que nos leva às misérias físicas e morais que se seguiram ao pecado.

A concupiscência, as misérias, a morte não são naturais, mas penais. São decorrências do pecado original. O homem primitivo não recebeu uma graça que o obrigasse a perseverar, mas teve uma que lhe permitia fazê-lo se o quisesse. Adão teve todos os bens necessários, muito mais do que temos hoje, porém preferiu se rebelar. Tinha mesmo uma vontade que se inclinava ao bem e não uma vontade meramente neutra como queriam os pelagianos. Essa neutralidade seria repugnante à bondade de Deus, de quem Adão era imagem. Mas o Criador deixou-lhe ainda a possibilidade de pecar e foi este o caminho escolhido. Como castigo justo por não ter usado o poder de não pecar, o homem perdeu esse poder.

As raízes penais de nossa condição miserável ficam claras se pensarmos que a onipotência de Deus não permite que nada escape à ordem universal que Ele impôs. Se o homem teve a liberdade de pecar é porque havia um castigo correspondente que recolocava as coisas dentro do plano divino.

Os pecados e castigos correspondentes não são naturezas, mas afecções das naturezas; os pecados são as voluntárias e os castigos são as penais. Mas a afecção voluntária de pecado é torpe, a qual segue a penal precisamente para colocá-lo no lugar que lhe corresponde, lugar onde não seja uma desordem na ordem do universo, ficando assim reparada a desonra do pecado pela pena correspondente. ${ }^{22}$

Em nossa natureza atual, o pecado gera o domínio da concupiscência, mal oposto a todas as exigências legítimas do espírito humano. Ela pode ser assim caracterizada: “(...) esta condição viciosa que faz que estes movimentos desregrados, acompanhados de estímulo a um gozo sem fim nem utilidade, se elevem em nós sem que o queiramos, ou mesmo contra a nossa vontade". ${ }^{23} \mathrm{O}$ movimento de nossos instintos é ruim quando se liberta de toda finalidade boa e espiritual. Os bens materiais, que deveriam ser meios para o encaminhamento 
espiritual, tornam-se bens em si mesmos. Esses impulsos se libertam da vontade e atuam contra nossas intenções, instaurando uma guerra entre o corpo e a alma. Essa luta, aliás, aponta para o fato de que essa não é nossa condição primitiva, pois não há porque duvidar que a harmonia e a paz caracterizavam o modelo original de Deus. Afinal, em hipótese, o fato de corpo e alma serem dois opostos não impediria que se harmonizassem, assim como a umidade e a secura se harmonizam no corpo saudável.

Mas condenar a concupiscência em si e não apenas em eventuais excessos não é reconhecer a existência de um princípio maligno positivo, ou seja, maniqueísmo?

Não (...) porque, longe de admitir dois princípios eternos ou de ensinar que houve algo de vicioso na origem de nossa natureza, nós sequer ensinamos que há algum mal positivo no estado atual da humanidade. Para nós, a concupiscência é apenas privação, uma qualidade defeituosa, falta de energia superior ou ainda um langor da alma. ${ }^{24}$

A concepção agostiniana do mal continua intacta: o mal não é uma criação positiva de Deus, mas é negação, privação, nada, e o nada não pode ser criado. $\mathrm{O}$ que não significa que não possa contaminar nossa natureza.

O abster-se de alimentos não é substância, contudo a substância corporal, se se priva de alimento, de tal modo se enfraquece, deteriora-se pelo desequilíbrio da saúde, consomem-se suas forças, se extenua e se abate que, se continua vivendo, é obrigada a voltar ao alimento, cuja abstenção foi causa de sua ruína. ${ }^{25}$

Analogamente, o pecado não é substância; mas, privando-nos do bem supremo (Deus), pode nos levar à morte eterna.

Resta-nos investigar, agora, se nesse quadro ainda é possível falar de um princípio de movimento e repouso teleologicamente orientado ou se o conceito já rompeu totalmente com o aristotelismo. O dinamismo próprio à idéia de natureza parece reduzido, após a queda, a um movimento de corrupção autônomo, cada vez mais aprofundado, que nada tem a ver com a intervenção da graça, a qual o interrompe. Isso não seria grave caso houvesse uma finalidade própria da natureza humana, corrompida ou não, que independesse da gratuidade. Todavia, vimos que Agostinho recusa-se a falar de uma natureza humana abstrata, limitando-se aos dois estados históricos: o adâmico e o decaído. Sendo assim, para falar de uma natureza humana, ainda que num 
sentido secundário em relação ao estado de inocência, devemos descobrir se o fim sobrenatural do homem de algum modo se manifesta no seio da corrupção em que o homem está inserido.

Em $A$ vida feliz, Agostinho mostra como é infeliz aquele que carece de algo e, mais ainda, que toda infelicidade é uma forma de carência ou indigência, enquanto a felicidade é a saciedade. Mas de quê? Os bens passageiros e sujeitos ao acaso não podem satisfazer o desejo humano, seja por sua própria transitoriedade, seja pelo receio de perdê-los que obrigatoriamente toma seu possuidor. Por isso, se alguém quiser ser feliz, deve buscar um bem permanente, que não lhe possa ser retirado por um revés da sorte. Ora, esse bem eterno e imutável é Deus. É feliz quem possui Deus e infeliz quem dele carece.

Não podemos, porém, dizer que Deus está em tudo e por isso tudo possui Deus? Em certo sentido, sim, mas aquele que vive em pecado possui Deus como distante e desfavorável. Já aquele que procura a Deus sem ter encontrado tem Deus propício a ele (do contrário, sequer o procuraria), mas nem por isso é feliz, pois não tem o que deseja, por mais que Deus lhe esteja presente de alguma maneira. É preciso encontrar Deus para ser feliz, o que só pode ser feito quando é sanada a carência suprema, aquela que contém todas as outras, a carência de Sabedoria.

\footnotetext{
Mas que sabedoria será digna desse nome, a não ser a Sabedoria de Deus? Justamente aprendemos pela autoridade divina que o Filho de Deus é precisamente a Sabedoria de Deus $(1$ Cor. 1, 24) (...) Quem é o Filho de Deus? Já o dissemos e está escrito: "A verdade!" Quem é aquele que não possui progenitor, a não ser a Suma Medida? Logo, todo aquele que vier à Suma Medida pela Verdade será feliz. E isso é possuir a Deus na alma, gozar de Deus. Quanto às outras coisas criadas, Deus as possui, mas elas não possuem a Deus. ${ }^{26}$
}

Esse é o fim a que nos destinamos, mas nem por isso podemos obtê-lo nesta vida, ainda que possamos buscá-lo com ajuda da graça. Qual é então o dinamismo produzido em nós pelo fim sobrenatural? Dinamismo que permite falar, mesmo que de modo precário, de uma natureza? Certamente não é o movimento da concupiscência, que nos conduz à destruição. Este é apenas conseqüência do pecado, levando-nos inutilmente a tentar preencher o vazio infinito de nossa carência. O movimento natural produzido por essa finalidade inatingível vivida como carência é outro: a inquietude. Como diz Agostinho, 
no início das Confissões: "Fizeste-nos para ti, e inquieto está o nosso coração, enquanto não repousa em ti." 27

Como explica Franklin Leopoldo e Silva,

na expressão "Fizeste-nos para ti" este para indica que, na produção divina da criatura, está posta a aspiração ao retorno como característica essencial da criação divina. O contato como aspiração ao retorno está, portanto, primeiramente colocado como marca divina, imagem de Deus, lembrança de Deus, memória do Absoluto, não apenas impressa, mas incluída por Deus na própria dinâmica da relação, o que faz com que a capacidade de Deus, o homo capax Dei, deva ser entendida no modo de uma divinização característica da obra divina quando dela resulta a criatura (grifos no original). ${ }^{28}$

Se a inquietude é imposta pela própria condição de criatura, que impõe uma aspiração irrealizável devido à distância desproporcional que a separa do criador infinito, por outro lado ela ganha uma nova dimensão com a corrupção do pecado: a condição humana é agora de miséria.

Se a passagem da inquietude ao repouso inclui as duas dimensões, é preciso ver como se ultrapassa esta oposição entre a grandeza de Deus e a miséria do homem. A posição de humildade confessional é o reconhecimento desta desproporção e desta oposição. Trata-se agora de identificar a condição presente do homem como situação de pecado com a inquietude enquanto aspiração a Deus. ${ }^{29}$

A corrupção não pode ser um caminho para o retorno, mas o mergulho na própria miséria pode dar o verdadeiro sentimento da nossa condição que nos move a pedir. A inquietude não nos garante o fim, mas aponta para o fim, fazendo de nosso movimento natural menos a atualização de possibilidades intrínsecas do que a prece ou a súplica pelo preenchimento do espaço desproporcional que nos separa daquilo de que mais carecemos. Sem a graça, não podemos sequer suplicar, mas isso não significa que a carência e a inquietude estejam menos presentes. Nossa natureza também aí estará, buscando sua completude no que não tem a mínima solidez.

27 AGOSTINHO, 1993, p. 15.

28 LEOPOLDO E SILVA, p. 3. Não publicado.

29 Ibidem, p. 4. 


\section{São Tomás}

No caso de Tomás de Aquino, a carência e inquietude agostinianas devem achar ressonância na noção de apetite natural, por isso é através desta noção que buscaremos compreender a concepção tomista de natureza. ${ }^{30}$

Na sua retomada cristã do pensamento de Aristóteles, Tomás opõe, de um lado, Deus, ato puro, logo sem movimento e sendo desde sempre o que deve ser, ao universo criado, que, de outro lado, está mergulhado no devir. Todo ser criado, assim, deve passar da potência ao ato, ou seja, à condição de ser realizado. Por conseguinte, o acabamento de uma natureza criada, ou melhor, seu fim, impõe um desejo natural desse fim, uma tendência de todo o ser para seu fim, e é precisamente isso que São Tomás denomina apetite natural. Diz o autor: "O apetite natural nada outro é que a inclinação da coisa a seu fim natural." 31

O fim, ou termo desse apetite natural, é o que define propriamente a natureza, dado que esta, ser inacabado, é concebida em vista do termo concreto a que se destina. É porque tem tal acabamento preciso a conquistar que a natureza é o que é no momento. Isso ocorre porque, como explica Laporta,

o fim é a primeira das quatro causas. Tudo que se passa, com efeito, explica-se sobretudo pelo fim que o agente persegue e que o sujeito alcança passando da potência ao ato. Todo ser criado passa do primeiro ato, sua natureza, ao segundo, seu fim. A natureza precede o fim sob o aspecto do tempo; mas sob o aspecto da causalidade o fim é o primeiro. ${ }^{32}$

Daí Tomás dizer no seu comentário da Física, 2.15.15, que o fim não é tal porque a matéria é tal, mas, antes, a matéria é tal porque o fim é tal.

Como Tomás explica no De veritate, 27.2.c, nas coisas naturais três coisas são pré-exigidas para a obtenção do fim: "a natureza proporcionada àquele fim, a inclinação àquele fim, que é o apetite natural do fim, e o movimento para o fim". ${ }^{33}$ Por isso estes quatro elementos (natureza, fim, apetite e movimento) são inseparáveis, ainda que, como explica Laporta,

só a natureza seja, ou possa ser, uma substância, o que é. Cada um dos três outros elementos, ao contrário, só pode ser um acidente, o que a coisa é. A pedra - essência subsiste. Ela tende para baixo, para aí se precipita e aí repousa: tender, cair, parar são acidentes, maneiras de ser da pedra. Mas se se distinguem estes acidentes da essência,

30 Neste percurso, seguiremos de perto a apresentação de Laporta (1965).

31 TOMÁS, S. Suma Teológica, 3, d. 27, q. 1, a 2. c, n. 39 apud LAPORTA, 1965, p. 24.

32 LAPORTA, 1965, p. 26.

33 Idem. 
eles não deixam de ser acidentes inseparáveis dela, que não podem ser modificados ou suprimidos sem que a própria coisa mude de natureza ou desapareça. ${ }^{34}$

Isso não significa, porém, que não haja seres que não alcançam seus fins e cujos movimentos naturais, portanto, não se completam nunca. Ao contrário, isso ocorre freqüentemente. A não-realização do fim, no entanto, não lhe tira o caráter de razão de ser da natureza e sua prioridade na ordem das causas, de modo que, alcançado ou não, continua sendo constitutivo da natureza. Já o apetite é inseparável da natureza num sentido ainda mais forte pois a natureza é inconcebível sem ele, mesmo quando não chega ao fim. Portanto, como diz Laporta, em termos escolásticos: "se o apetite natural é um acidente no sentido predicamental, não o é jamais no sentido predicável; ou seja, se o apetite natural é um acidente por oposição a uma substância, não pode ser um acidente por oposição ao necessário". ${ }^{35}$ É claro que o apetite natural é algo "em outro", não é "por si" como a substância, mas nem por isso será um acidente no sentido de que podia não ter existido. Sem ele, a substância é destruída.

Tudo que até aqui foi dito vale para a totalidade da criação e não apenas para os seres providos de intelecto:

Do mesmo modo ordenam-se para o fim as coisas que o conhecem e as que o desconhecem; as que o conhecem para ele se dirigem por si mesmas; as que o desconhecem, no entanto, tendem para o fim como dirigidas por outra coisa, como se vê, por exemplo, na flecha e no flecheiro. Além disso, as coisas que conhecem o fim sempre se ordenam para o bem como para o seu fim, pois a vontade, que é o apetite do fim previamente conhecido, não tende para coisa alguma senão em razão do bem, que é o seu objeto. Logo, também as coisas que não conhecem o fim ordenam-se para o bem, como para o seu fim. ${ }^{36}$

Tudo tem um fim e um apetite natural. A vontade, no entanto, não é o próprio apetite natural dos seres intelectuais. O fim dela, sem dúvida, aproximase do fim dos seres intelectuais, já que a razão de ser dela é justamente experimentar a felicidade de um ser intelectual que alcançou sua destinação. Todavia, a beatitude em si mesma é objeto do intelecto, não da vontade, por conseguinte, o fim a que se destina o apetite natural dos seres intelectuais será um conhecimento. Diz Tomás: 
Com efeito, sendo a beatitude o bem próprio da natureza intelectual, é necessário que esta concorde com aquilo que lhe é próprio. Ora, o apetite não é próprio só da natureza intelectual, mas está em todas as coisas, embora diversamente. Essa diversidade, no entanto, provém do relacionamento diverso das coisas com o conhecimento. Com efeito, as coisas totalmente destituídas de conhecimento têm somente apetite natural. As que têm conhecimento intelectivo têm o seu apetite proporcional ao conhecimento, isto é, a vontade. Por isso a vontade, enquanto apetite, não é própria da natureza intelectual, mas somente enquanto depende do intelecto. Ora, o intelecto considerado em si mesmo é próprio da natureza intelectual. Logo, a beatitude, ou felicidade, consiste primeira e essencialmente em ato do intelecto, mais do que em ato da vontade. ${ }^{37}$

Evidentemente, isso não nos impede de dizer que um apetite natural liga a vontade à beatitude. Esta é o fim a que se destina aquela, mas apenas na medida em que se subordina ao intelecto:

Primeiramente e por si mesmo o intelecto move a vontade, pois a vontade, enquanto tal, é movida pelo seu objeto, que é o bem apreendido pelo intelecto. Ora, a vontade move o intelecto quase acidentalmente, enquanto a intelecção é apreendida como bem e, assim, é desejada pela vontade, resultando disto ter o intelecto conhecimento atual. E até nisto o intelecto precede a vontade, pois jamais a vontade desejaria o conhecimento do intelecto se o intelecto não apreendesse o seu próprio conhecimento como um bem. Além disso, a vontade move o intelecto para a operação atual à maneira de agente, e o intelecto move a vontade à maneira de fim, pois o bem por ele conhecido é o fim da vontade. E ainda, quanto ao mover, o agente é posterior ao fim, pois ele não move senão para o fim. Depreende-se disso que o intelecto é simplesmente superior à vontade. ${ }^{38}$

Esse fim da vontade, porém, pode passar despercebido, atraindo-a sem que haja consciência disso, o que fere aquela definição de vontade como apetite do fim pré-conhecido. Por isso, mostra Laporta que encontramos para a vontade um segundo apetite natural, este sim um fato psicológico observável, para além daquele apetite natural metafísico que é comum a todas as coisas:

Estar satisfeito e sentir sua perfeita satisfação são coisas diferentes. As plantas são felizes sem o saber; o animal, ao contrário, pula de alegria quando alcança seu objetivo. Isto a que a vontade tende por natureza é experimentar o supremo apaziguamento do ser racional. Isto supõe a beatitude já realizada, a vontade acrescentando-lhe sua alegria suplementar. A beatitude constitui uma realidade concreta, o termo definitivo de evolução de uma natureza intelectual. Eis o objeto do apetite natural metafísico da vontade. Em sua atividade consciente, ao contrário, a vontade só persegue a beatitude através de um conceito vago, através da imaginação. ${ }^{39}$ 
É na medida em que a vontade é atraída, de maneira forçosamente consciente, por esse ideal vago, que ela se enquadra na definição anterior de apetite do fim previamente conhecido. Isso não significa, porém, que ela acerte: "Ora, a verdadeira beatitude não se diferencia da falsa pelo ato da vontade, pois a vontade se mostra igualmente desejando, amando, ou se deleitando, o que quer que se lhe proponha como seu bem, seja ele verdadeiro ou falso." ${ }^{40}$ Como explica Laporta, este sempre perseguido ideal vago cada vez se encarna em um objeto real, no que a vontade é no mais das vezes decepcionada, permanecendo insatisfeita. Daí a importância da seguinte distinção:

Quando se fala do apetite natural de um homem, pode-se ter em vista o desejo natural consciente, que só pode ser seu desejo natural sensível ou voluntário. Mas quando se fala mais corretamente do apetite natural do ser humano, e não mais precisamente ou somente de sua vontade, não se trata mais de uma atividade psicológica, mas da finalidade desta natureza. ${ }^{41}$

E o que é a beatitude, o fim das substâncias intelectuais? Antes de mais nada, é preciso explicitar qual é o fim de todas as coisas.

Com efeito, se nenhuma coisa tende para algo como para seu fim senão enquanto este é bom, necessariamente o bem enquanto bem identifica-se com o fim. Por conseguinte, o que é o sumo bem será o fim supremo de todas as coisas. Ora, o sumo bem é um só, que é Deus, como foi provado no livro I (cap. XVII). Logo, todas as coisas se ordenam como para seu fim, para um só bem, que é Deus. ${ }^{42}$

Contudo, isso não significa que todas as coisas se ordenem a Deus da mesma maneira; o farão de acordo com as respectivas naturezas. Donde se coloque a pergunta sobre a maneira própria das substâncias intelectuais, cuja resposta não poderia ser outra:

A operação própria de qualquer coisa é o seu fim, que é a sua segunda perfeição. Ora, a intelecção é a operação própria da substância intelectual e é o seu fim. Por isso, o que é perfeitíssimo nesta operação é o fim último, sobretudo nas operações que não se ordenam a efeitos exteriores, como são os conhecimentos sensitivo e intelectivo. Ora, como essas operações recebem a especificação dos objetos, pelos quais também são conhecidas, é necessário que tanto mais perfeita seja uma delas quanto mais perfeito é o objeto. Por isso, entender o inteligível perfeitíssimo, que é Deus, é o que há de mais perfeito no gênero do conhecimento intelectivo. Logo, conhecer a Deus intelectualmente é o fim último de toda substância intelectual. ${ }^{43}$ 
Mas Tomás vai mais longe e se pergunta, no capítulo 38, em qual conhecimento de Deus consistirá a felicidade última dos seres intelectuais. Não será no conhecimento comum e confuso que quase todos os homens têm do ser supremo, nem no conhecimento oriundo das demonstrações filosóficas que corrigem aquelas noções elementares, e nem sequer no conhecimento que se tem pela fé, todos eles ainda imperfeitos e incapazes de saciar completamente o desejo de conhecer do homem, logo ineptos para ser o fim último dos seres intelectuais. O problema é que isso aponta para a impossibilidade de o homem alcançar sua felicidade última nesta vida:

O fim último do homem lhe põe termo ao apetite natural e, assim, sendo ele atingido, nada mais se deseja, e se o homem tem ainda algum desejo, é porque não atingiu o fim no qual repousa. Ora, isso é impossível acontecer nesta vida. Com efeito, quanto mais alguém conhece, tanto mais se lhe aumenta o desejo de conhecer, o que the é natural, a não ser que casualmente houvesse alguém que conhecesse tudo. No entanto, isso não acontece nesta vida a quem se diga homem. ${ }^{44}$

O conhecimento capaz de satisfazer nosso desejo natural é o que nos dará nada menos do que a visão da essência de Deus. Isso, porém, além de extrapolar os limites desta vida, parece extrapolar os limites naturais da substância criada:

A semelhança na ordem inteligível, pela qual se conhece uma coisa segundo a sua substância, convém que seja da mesma espécie, ou melhor, que seja a própria espécie. Assim, por exemplo, a forma da casa que está na idéia do construtor tem a mesma espécie da forma da casa construída, ou melhor, é a sua própria espécie, até porque também pela espécie de homem não se conhece a do burro ou do cavalo. Ora, a natureza da substância separada não é da mesma espécie que a natureza divina, nem até do mesmo gênero, como foi demonstrado (livro I, cap. XXV). Logo, não é possível que a substância separada conheça a substância divina pela sua própria natureza. ${ }^{45}$

Todavia, Tomás reafirma o axioma "o desejo natural não pode ser vão, já que a natureza nada faz em vão (livro II do De caelo)", o que lhe permite afirmar não só que teremos outra vida em que a beatitude será possível, mas de que maneira a visão será possível: "foi acima demonstrado (cap. XLIX) que a substância divina não pode ser vista pelo intelecto mediante uma espécie criada. Donde ser necessário, sendo Deus visto em sua essência, que pela mesma essência divina o intelecto a veja, de modo que nesta visão a essência 
divina seja o que é visto e aquilo pelo qual é visto". ${ }^{46}$ O que exige o axioma aristotélico não é pouco: para que o desejo natural de beatitude se realize, será preciso que a forma de Deus se torne forma do intelecto criado que a vê. Ora, isso está muito além do alcance da natureza criada, pois ver Deus pela essência divina é algo próprio da natureza divina, e só dela. Diz Tomás:

Ora, ver Deus por essência transcende os limites de toda natureza criada, pois é próprio de toda natureza intelectual criada conhecer segundo o modo de sua substância, e a substância divina não pode ser assim conhecida, como foi demonstrado (cap. XLIX). Logo, é impossível a um intelecto criado chegar à visão da substância divina, a não ser pela ação de Deus, que transcende toda criatura. ${ }^{47}$

Em outras palavras, e este é um ponto crucial para compreender a noção de natureza humana, a criatura intelectual é definida por um fim que ela não pode alcançar por suas próprias forças. Digo criatura intelectual, e não só o homem, pois isso não se limita a uma natureza decaída, mas estende-se a qualquer natureza intelectual criada. A natureza parece exigir a sobrenatureza.

A correta compreensão dessa aparente contradição passa pela noção de potência passiva natural. Como explica Laporta,

todo movimento no universo é fundado sobre duas potencialidades: poder sofrer o ato, tornar-se: potência passiva; poder pôr o ato, agir: potência ativa. A potência passiva, por sua vez, ou é potência passiva natural: poder evoluir conforme a sua natureza; ou é potência passiva não-natural: poder sofrer uma mudança não conforme a sua natureza. Diante da evolução normal do ser, desenvolvendo-se em vista de seu fim, a potência passiva é natural. Mas, de fato, ocorre às vezes e mesmo freqüentemente no mundo que o sujeito evolua como ele não desejaria desenvolver-se, torna-se o que, por sua natureza, ele não era chamado a tornar-se. Por acidente, por artifício, por violência, ele passa a um estado não conforme a sua finalidade. $\mathrm{O}$ cordeiro não tende por natureza a tornar-se alimento do lobo. Deste ponto de vista, todo ser tem uma potência passiva não natural, simples submissão ao que ele pode tornar-se contrariamente a seu impulso espontâneo. ${ }^{48}$

Por requerer um agente natural que a atualize, a potência passiva assume um acento diverso do apetite natural, mas ambos tendem ao mesmo fim, a plena realização da natureza em questão, de modo que, embora sejam coisas diversas, o ato de ambos é o mesmo. Sendo assim, a potência passiva pode abarcar um leque bem mais amplo de possibilidades, mas a potência passiva natural é uma só, definida estritamente pela natureza do sujeito, que comporta 
uma só finalidade. O questionamento levantado por Laporta é a respeito da potência passiva natural para o sobrenatural, que, segundo o comentador, Tomás ora afirma, ora nega.

O agente que atualiza uma potência pode ser natural ou não natural. Sendo natural, ele será tão determinado pelo fim quanto o apetite natural, do qual não se desvincula:

É agente natural aquele que age segundo sua natureza, realizando tal ato concreto que constitui sua razão de ser. Ele existe em vista de uma tarefa definida a realizar: natum facere hoc, nascido para fazer isto. Sua maneira de ser, sua estrutura se explica por um papel preciso a assumir. Tudo o que ele é foi concebido e moldado em vista de uma missão determinada a cumprir. Ele é o que é em vista de um ato a realizar. ${ }^{49}$

Ora, se tomarmos os atos naturais, aqueles que realizam um apetite natural e são feitos por agentes naturais, Deus não pode ser o agente natural deles, pois não é determinado naturalmente a aquele fim. Sendo assim, poderíamos ser levados a pensar, como o tomista Cajetan, que, não havendo potência natural sem agente natural, a potência da natureza para o sobrenatural, ou seja, para a graça e a visão beatífica, não pode ser uma potência passiva natural, mas apenas uma potência obediencial. Esta, para Tomás, seria:

Uma potencialidade passiva, pela qual toda criatura, enquanto tal, pode tornar-se não aquilo a que tende por natureza, mas qualquer outra coisa que agrade ao Criador fazer dela. Em outros termos, capacidade comum a todos os seres criados de evoluir fora do curso normal de seu desenvolvimento, graças a uma intervenção divina. ${ }^{50}$

Em outras palavras, trata-se de um milagre divino.

A posição de Tomás, porém, como mostra Laporta, não é tão cristalina. No Compêndio de teologia, Tomás nega categoricamente a potência passiva natural com relação à visão beatífica: "algo está naturalmente em potência a respeito das coisas que podem ser reduzidas a ato pelo agente natural". ${ }^{51} \mathrm{Ou}$ seja, se a visão é inacessível à criatura, não há potência passiva natural. Por outro lado, no IV Escrito sobre as sentenças e na Suma teológica, Tomás se pergunta se a justificação do ímpio é um milagre. Para sê-lo, deveria, além de constituir uma ação realizável apenas por Deus, cumprir um dos dois requisitos: ou bem realizaria uma potência passiva natural do sujeito, mas com um agente sobrenatural substituindo o agente natural, ou bem não realizaria 
nenhuma potência natural do sujeito, caindo no caso da potência obediencial. Ora, Tomás responde que a justificação dos ímpios não é milagre, pois: “1) quanto à graça, há uma potência, de modo algum obediencial, mas natural; 2) e esta potência natural é cumprida pelo único agente natural adequado, Deus, não substituindo, desta vez, nenhum agente natural. Assim, nem o primeiro nem o segundo tipo de milagre se realizam; tudo permanece normal". ${ }^{2}$

Em resumo, para manter válido o axioma "O desejo natural não pode ser vão", Tomás precisa cindir o conceito de potência passiva natural. Como capacidade de ser realizada por um agente natural, a potência passiva natural para o sobrenatural não está no homem, já que só Deus a atualiza. Como capacidade de evoluir conforme seu impulso natural, ela está presente, pois é Deus, o único agente natural apropriado para atualizá-la, que realiza o fim que constitui a natureza humana. Essa distinção, porém, não dissolve o desequilíbrio de fundo da natureza humana. Como em Agostinho, é infinita a distância entre o que a criatura intelectual necessariamente deseja e o que ela pode conquistar por si mesma. Esse desequilíbrio, por sua vez, aponta para a grandeza da criatura humana:

O fim último do homem consiste em um certo conhecimento da verdade que the excede a capacidade natural, isto é, em ver a verdade primeira em si mesma, como acima foi demonstrado (cap. 50 e ss). Ora, não é próprio das criaturas inferiores atingir um fim que lhes exceda a capacidade natural. Por isso, é conveniente que, também por causa desse fim, sejam vistos os diversos modos de governos, referentes ao homem e referentes às criaturas inferiores. Com efeito, as coisas destinadas a um fim devem ser proporcionadas a ele. Se, pois, o homem está destinado a um fim que lhe excede a capacidade natural, é necessário que lhe seja acrescentado um auxílio sobrenatural, mediante o qual tenda para o fim..$^{53}$

Como dissemos antes, o fim é pensado em relação à natureza. Logo, se a natureza humana se destina a um fim inalcançável por suas próprias forças e, nesse sentido, sobrenatural, essa qualificação deve ser considerada secundária e subordinada. O natural, no sentido forte, é a finalidade inscrita na natureza. Mesmo que se fale de um fim natural proporcionado a nossas forças, a saber, a contemplação da verdade tanto quanto é possível nesta vida, trata-se apenas de um fim provisório, que, como Tomás explica (Suma contra os Gentios III, 63), está contido no verdadeiro fim natural, a visão beatífica. Por isso a graça, auxílio sobrenatural necessário para merecermos a justificação, está contida na potência passiva natural, completando a natureza. Se trouxesse um novo 
fim para a natureza humana, a graça sequer seria desejável, pois mudar o fim é destruir a natureza em questão.

Isso não significa, porém, que todos devam chegar à visão beatífica. Como já dissemos, muitos são os seres que não realizam seu fim; mas o irrealizado não é o irrealizável. Com o auxílio apropriado, o homem pode salvar-se, todavia, se esse lhe for negado, nem por isso sua natureza será destruída. Sem a graça, o homem permanece com o mesmo apetite e o mesmo fim naturais, por mais irrealizados que sejam, e pode até ser feliz (de uma maneira bastante imperfeita). Mesmo incapaz de merecer a graça (Suma contra os Gentios III,149), o homem não está condenado à miséria, só à imperfeição. Mais uma razão para constatarmos que o deus tomista não deve a salvação a ninguém; mesmo assim, e até por isso, a natureza humana persiste intocada. Nas palavras de Laporta,

\begin{abstract}
criando uma natureza intelectual, Deus não é obrigado a dotá-la das forças necessárias para realizar seu destino? Evidentemente não. Deus não é obrigado a realizar contradições. Ele não pode produzir uma criatura com atributos divinos. Não pode criar um ser capaz por natureza de ver Deus. Não pode também produzir uma criatura que possuiria por natureza, ou poderia adquirir por sua atividade natural, um direito qualquer de ir viver com ele. ${ }^{54}$
\end{abstract}

Como em Agostinho, a gratuidade é necessária ao pensamento tomista da natureza.

\title{
A teologia moderna
}

Apresentadas as doutrinas de Agostinho e Tomás, as matrizes maiores do pensamento cristão, podemos passar à teologia moderna e à maneira como ela lidou com a idéia de natureza humana. $O$ primeiro nome a destacar, este tradicionalmente ligado ao agostinismo, é o de Baius. Como Agostinho, Baius também afirma que é necessário ao homem o socorro externo de Deus para que possa realizar seu destino. Também como Agostinho, não concebe um estado em que o homem, reduzido a suas próprias forças, chegaria a sua perfeição como pura natureza, sem intervenção da graça. A maneira como os dois autores vêem a graça e a relação do homem com ela é, contudo, bastante diversa. Nas palavras de Lubac: 
De uma tese que, sob sua forma negativa, parecia totalmente idêntica, Agostinho concluiu que nada no homem escapa à graça; Baius, que a graça nada tem a ver, senão em um sentido impróprio, com o homem inocente: pela própria lei da natureza, o homem tem sobre Deus direitos estritos, de modo que o indispensável socorro divino não é mais a iniciativa ditada por um transbordamento gratuito de bondade, mas o pagamento de uma dívida de justiça. Segundo Agostinho, este socorro tem por efeito nos elevar, nos alçar a uma condição feliz que de modo algum é merecida por um esforço criado; segundo Baius, ele é apenas um meio necessário posto à nossa disposição para nos permitir merecer humanamente com um mérito que, por sua vez, exige sua recompensa. ${ }^{55}$

A proximidade com Pelágio é evidente, mas ao mesmo tempo surpreendente para um teólogo agostiniano. Se Pelágio naturalizava os instrumentos necessários para concretizar a natureza, e portanto naturalizava a graça, Baius faz desse instrumento o objeto de uma dívida de Deus para com a natureza humana, que sequer merece o nome de natureza sem o pagamento:

O que Deus lhe dá não é recebido como um benefício: é-lhe ainda algo de natural; não, sem dúvida, natural por constituição, como teria dito Pelágio, mas natural por exigência. Não é, falando rigorosamente, uma parte integrante de sua natureza, mas não é menos algo indispensável à integridade desta natureza e, por conseguinte, essencialmente requerido por ela. ${ }^{56}$

Sem a graça, não haveria integridade na natureza humana (o que não seria diferente em Agostinho ou Tomás), mas o resultante não seria um bem menor, e sim um mal, algo contra a natureza. Desse modo, a graça não é apenas um aperfeiçoamento da natureza, mas um complemento lógico e necessário da criação. Baius busca mostrar, como vimos em Tomás, que não é incompatível falar de um fim sobrenatural para a natureza humana; o que faz desse sobrenatural, no limite, um fim natural. Todavia, Baius vai diretamente contra a letra de Tomás ao fazer da obtenção desse fim uma obrigação divina. Tomás diz:

Por sua primeira instituição a natureza humana foi ordenada ao fim da beatitude, não como a um fim devido ao homem segundo sua natureza, mas apenas pela liberalidade divina; e por isso não cabe que os princípios da natureza bastem para obter o fim, exceto se forem acrescidos de dons adicionais pela liberalidade divina. ${ }^{57}$

55 LUBAC, 1965, p. 16.

56 Ibidem, p. 18.

57 TOMÁS, De veritate, 14.10.2 apud LAPORTA, 1965, p. 122. 
Para Baius, a carência do fim não se apresenta como inquietude (à maneira de Agostinho) ou apetite (São Tomás), mas como a cobrança de um direito (aos meios).

Mesmo após o pecado, a dependência da graça divina tem em Baius um caráter bem diverso do de Agostinho. Para o moderno, no homem corrompido a intervenção divina em vista do ato salutar não é mais devida, mas essa gratuidade não incide sobre a essência mesma do ato:

O que constitui este ato sendo, segundo ele, como se viu, apenas o fato da obediência à lei, fato que acarreta como recompensa a glória celeste, segue-se que o socorro e a presença mesma do Espírito Santo, obtidos pela redenção de Cristo, são apenas uma pura condição deste ato ou, no máximo, um puro instrumento. ${ }^{58}$

Como instrumento, a graça é, sim, condição necessária do ato meritório, mas não constitui este mérito, não transfere ao homem uma dignidade sem a qual não há mérito. Portanto, mesmo após o pecado, não se pode dizer que o mérito seja dom divino, o que afasta Baius do mestre Agostinho. Como diz Lubac, "quaisquer que sejam as colaborações divinas, o resultado permanece inteiramente humano. A graça precede o ato do justo, mas não se poderia dizer que o informa; ela o torna possível de fora, ela não o sustenta por dentro". ${ }^{9}$

Foi em grande parte no intuito de rejeitar a heresia baiana que a escolástica tardia desenvolveu um conceito que, se talvez já estivesse implícito, ao menos não era evidente na tradição teológica: a pura natureza. Essa idéia, cuja perfeita formulação só se dará em Suarez, visava antes de tudo impugnar a ilação de que, se a graça é necessária para realizar plenamente a natureza humana, ela é devida por Deus ao homem. Este pode, ao contrário, realizar de maneira puramente natural os seus desejos naturais, com instrumentos naturais, chegando por fim a uma felicidade puramente natural que não depende da intervenção gratuita. Perde completamente o sentido, portanto, a idéia de dívida.

Sigamos Lubac, mais uma vez, na sua tentativa de rastrear as origens do conceito de pura natureza: a primeira fonte apontada pelo comentador para tal idéia foram as especulações medievais em torno da potência absoluta de Deus, a qual poderia perfeitamente produzir um semelhante estado. Tais especulações, contudo, não questionavam de fato a tese tradicional sobre o fim último do homem. A segunda fonte para a idéia vinha de um problema teológico bastante concreto: 
$\mathrm{O}$ caso das crianças mortas sem o batismo, às quais não se podia conceder a visão beatífica, e que não se aceitava danar como os pecadores, devia levar a pôr a hipótese, esta concreta, mas no interior de nosso mundo atual, de um estado intermediário. Por analogia, visava-se o caso, não realizado, em que o primeiro homem teria morrido antes de ter recebido a infusão da graça santificante, e por conseguinte antes de ter feito a opção moral que foi, de fato, o pecado original. ${ }^{60}$

Tratava-se, no entanto, de um caso excepcional, que por isso não podia servir de modelo para a condição humana em geral. A última fonte, segundo Lubac, seriam as especulações dos humanistas do século XV que elaboraram a idéia de religião natural. A partir daí, vários teólogos do início do século XVI começaram a tratar do tema, mas sempre como uma "ficção útil" e sem criar uma dualidade de fins últimos. Mesmo que considerassem a possibilidade de um fim puramente humano, este estava sempre subordinado ao verdadeiro fim, a visão beatífica, no que os teólogos modernos nada diferiam de Agostinho e Tomás. Pode-se constatar isso no próprio Catecismo do Concílio de Trento, publicado em 1566.

Belarmino, na sua refutação a Baius, traz algo novo. À objeção de que ao homem, cujo fim natural é ver Deus, são-lhe devidos os meios para isso, o autor responde com uma argumentação de cunho tomista:

Digo que este devido, qualquer que seja, não é natural, mas sobrenatural, pois Deus quis criar o homem para um fim tão sublime que não se poderia atingir senão por meios sobrenaturais. Com efeito, deve-se observar que a visão de Deus não é dita fim natural do homem de tal modo que o homem possa alcançá-la naturalmente, mas somente que a natureza seja capaz da visão de Deus e que o homem apeteça naturalmente ver Deus. ${ }^{61}$

Em outras palavras, o fim é natural quanto ao apetite, mas sobrenatural quanto à consecução, o que não indica a miséria da condição humana e sim sua grandeza, o fato de ser à imagem de Deus. Até aqui, nada de novo. Mas então Belarmino aprofunda, ainda com argumentos tomistas, a objeção de Baius:

O homem não pôde ser criado para um fim inferior à visão de Deus, logo eram-lhe simplesmente devidos os meios para tal fim. Prova-se o antecedente: pois o intelecto humano naturalmente é capaz da visão de Deus e a apetece naturalmente, e não pode ocorrer que não seja capaz dela, do contrário não seria intelecto, mas algo inferior. ${ }^{62}$

Ou seja, se o homem tivesse outro fim, sua própria natureza mudaria.

60 LUBAC, 1965, p. 140.

61 BELARMINO, Sententiae D. M. Baii refutatae apud LUBAC, 1965, p. 186.

62 LUBAC, 1965, p. 187. 
Curiosamente, aí onde parece nada restar para a idéia de uma pura natureza, desvinculada dos fins sobrenaturais, Belarmino vê a ocasião para introduzir a idéia:

Teria sido equânime que Deus, tendo ordenado o homem a tal fim tão elevado, não lhe negasse os meios necessários; porém nada absurdo seguiria se negasse. Pois embora aquela suma beatitude seja o fim natural do homem, é um fim desproporcionado e, além dele, tem outro fim natural inteiramente proporcionado a si, o qual é investigar a verdade pelo raciocínio. Por isso pôde Deus conduzir o homem pelos meios naturais ao fim proporcionado a sua natureza e não elevá-lo mais. Temos exemplo disso no pássaro da noite, que tem a capacidade natural e o apetite de ver o sol, e contudo é crível que nunca ocorrerá que veja o sol, mas só aquela luz débil e obscura que é objeto dos olhos, não apenas natural mas também proporcionado. ${ }^{63}$

O pássaro da noite não vê o sol, como estaria em sua capacidade e seu apetite, mas nem por isso é uma potência vã. Ele tem uma atualização proporcionada a suas capacidades, pela qual vê muitas outras coisas. Do mesmo modo, o homem, por seu intelecto, está destinado à visão de Deus, mas nem por isso é uma potência vã, pois pode ver o que está ao seu alcance. Não se trata, evidentemente, de Beatitude, palavra que Belarmino não usa para esse fim puramente natural, mas é sim uma realização suficiente para impedir a conclusão do raciocínio de Baius. O instrumental de Belarmino vem todo de Tomás, mas o acento deve mudar, já que Tomás não tinha um adversário tão perigoso quanto Baius. Por isso o que era um fim secundário e subordinado deve agora adquirir relativa autonomia, dando espaço para a idéia de pura natureza.

É somente com Suarez que a nova teoria se delineia mais perfeitamente. Ele sistematiza a idéia de pura natureza, integrando-a à doutrina dos estados da natureza humana ${ }^{64}$ Além do estado adâmico e do estado de natureza decaída, temos agora o estado de pura natureza, embora esse não corresponda a nenhum momento de fato existente na história humana, sendo apenas um modelo teórico para pensar o homem enquanto tal, ponto de partida necessário de qualquer dos chamados estados históricos:

O estado da natureza humana é dividido pelos teólogos em dois gêneros, a saber, o de via e o de termo, isto é, o estado desta vida, que é o da beatitude a ser adquirida, e o estado da pátria, que é o da beatitude já possuída. (...) Não falaremos do segundo (...). Tratemos então do estado de via, que os teólogos antigos distinguiram em apenas

63 BERLARMINO, De gratia primi hominis apud LUBAC, 1965, p. 191.

64 Quanto a isso, destacamos Suarez não por ineditismo da teoria, mas pelo rigor da formulação e pela influência que teve. 
dois, o estado de natureza íntegra e o de natureza decaída, como vemos por ex. em S. Tomás 1. 2, q. 109 inteira, Gabriel in 4, dist. 1, q. 2, entre outros. Contudo esta divisão é dada sobre os estados que, em diversos tempos, a natureza humana de fato teve; ora, supomos que nenhum deles é o estado de pura natureza. Pois, como abaixo mostraremos aos heréticos e a alguns católicos, ambos acrescentam algo ao que a natureza humana por si mesma postula; e por isso Cajetan e os teólogos modernos consideraram um terceiro estado, que chamaram puramente natural e que, embora não tenha existido, como suponho e abaixo mostrarei por uma sã doutrina, contudo pode ser pensado como possível, e a consideração dele é necessária para a inteligência dos outros, já que na verdade este estado é como que o fundamento deles. ${ }^{65}$

Quanto ao conteúdo propriamente dito desse estado, ele inclui todas as faculdades naturais, corporais ou materiais, contidas na potência humana, bem como o concurso e a providência de Deus naturalmente devidos, ou seja, necessários para a atualização das potencialidades naturais. Por outro lado, ele exclui tudo o que seja acrescido à natureza, a ela não devido, seja mal ou bem, a saber, nem o pecado, nem a culpabilidade dele decorrente, nem o dom da graça ou outras perfeições não devidas à natureza. A parte positiva, segundo Suarez, não gera disputa, por isso discutirá com mais atenção as coisas que o estado de natureza exclui. Diz o autor: "Deus não pode ser o autor do pecado, e por isso deve-se conceder que a natureza não infunde culpa, mas é necessário que ela se derive de outra raiz infecta, como ocorre no pecado original, ou nasça da própria vontade criada." ${ }^{66}$ Portanto, independentemente do que hoje ocorre, não há contradição em pensar o homem sem pecado ou culpa. Desde que o consideremos criado imediatamente por Deus, tal possibilidade está garantida, e isso basta para a constituição de uma hipótese como é o estado de pura natureza.

Quanto a pensar o homem sem a graça, a situação é mais complexa, porque de fato Adão a recebeu imediatamente de Deus na criação:

Além de todas as faculdades naturais, o homem tem uma perfeição especial, que consiste na ausência de impulso e desenfreada concupiscência, ou seja, na perfeita submissão do apetite sensível ao racional. ${ }^{67}$ Por outro lado, quando perdeu esta graça, não ficou em situação neutra, mas caiu em pecado: nenhuma criatura, uma vez tendo a graça, pode ser dela privada por Deus se não privar-se dela pecando. Donde vem aquele axioma católico: o justo não é abandonado por Deus se primeiro ele próprio não abandona Deus. Logo não pode ter passado do estado de graça ao estado de pura natureza, mas só ao estado de culpa. E, inversamente, também não pode passar do estado de culpa ao estado de pura natureza. ${ }^{68}$ 
Quanto à ausência simultânea de graça e pecado, não há nem pode haver suporte de fato para a hipótese da pura natureza. Como sustentá-la de direito?

Para garantir a possibilidade da pura natureza, Suarez precisa, antes de mais nada, desfazer o equívoco em torno do termo "natural":

Costuma-se às vezes chamar natural a tudo que o homem tenha junto com a natureza, como na sentença "Éramos filhos da ira por natureza", e assim pode ser dito que a integridade da natureza foi conatural a Adão, dado que foi concriada com ele. Contudo agora não falamos assim, pois deste modo também a graça pode ser dita conatural aos anjos e ao primeiro homem. Propriamente falando, chama-se natural não a tudo que seja dado no instante da criação, mas ao que de algum modo é dado pela força da própria natureza. ${ }^{69}$

Além disso, como a própria noção de estado é vista pelo autor como uma certa proporção da natureza humana em ordem a um fim último, é preciso demonstrar que o fim último do homem, sua beatitude, não implica necessariamente a noção de graça. Sem isso, o conteúdo do estado de pura natureza se reduz ao de natureza íntegra e Baius será irrefutável.

Como explica Lubac, Suarez parte da idéia de que o homem, como substância natural, deve tender a um fim nos limites da natureza, ou seja, um fim último conatural:

O fim de um ser natural é sempre rigorosamente mesurado aos seus meios. Eis aí, para Suarez, um princípio absoluto, e não menos absoluta, não menos indiscutível é a aplicação deste princípio ao caso do homem. Em virtude de sua criação, o homem é portanto feito para uma beatitude de essência natural. ${ }^{70}$

Como Belarmino, Suarez sente a força da argumentação de Baius, por isso aceita partir do mesmo ponto que ambos: "toda potência inclina-se naturalmente ao ato a si conatural, sobretudo ao perfeitíssimo, pois todo perfectível apetece sua perfeição. Ora, a beatitude, como se diz freqüentemente, é a máxima perfeição, e se é natural, é também proporcionada". ${ }^{71}$ O que marca a diferença de Suarez é o destaque dado à idéia de proporcionalidade entre o ser natural e seu fim e, sobretudo, o fato de não temer o uso do termo "beatitude" para caracterizar esse fim natural, o que não ocorria em Belarmino.

Evidentemente, o homem pode, e no caso dos eleitos vai, ser chamado a um fim superior, mas, desproporcionado aos meios naturais. Tal fim é acrescentado 
sem alterar a natureza do ser em questão, permanecendo a mesma a beatitude natural, por si mesma suficiente para realizar o homem enquanto tal. E o que ela é? "Deve-se dizer que ela consiste na perfeitíssima conjunção natural com Deus pelo intelecto e pela vontade, tanto quanto pode ser conhecido pela luz natural do intelecto da criatura." 72 Mas tal beatitude natural não é a visão beatífica prometida aos eleitos. Esta última não é a felicidade própria do homem, não é constitutiva de sua natureza e por isso não pode sequer ser naturalmente desejada. Desse modo, a idéia de que a visão beatífica é o fim natural quanto ao apetite, ainda que sobrenatural quanto à consecução (chave da solução tradicional), não podia ser aceita, pois abriria uma brecha para descaracterizar a beatitude natural como verdadeira beatitude. Daí dizer Suarez:

O apetite inato é fundado na potência natural, mas no homem não há potência natural para a beatitude sobrenatural. Logo não há apetite inato, o que pode ser confirmado pelo que decorre dos princípios acima postos, já que mostramos haver no homem outra beatitude, natural, além desta sobrenatural, e conseqüentemente ele apetece aquela pelo apetite inato. Apetece portanto aquela como sua perfeição última, do contrário não a apeteceria como beatitude. Logo não apetece a beatitude ulterior com aquele apetite, já que, assim como é impossível haver dois fins últimos a respeito do mesmo, assim também é impossível apetecer naturalmente duas perfeições como últimas, ou seja, o que é o mesmo, como beatitude. ${ }^{73}$

Suarez sabe que sua teoria rompe com Agostinho (Fizeste-nos para ti, e inquieto está o nosso coração, enquanto não repousa em ti.) e Tomás, ou pelo menos com uma certa tradição interpretativa deste último. Por isso deve destacar em Tomás alguma ambigüidade que ao menos permita a leitura favorável à pura natureza: "S. Tomás não parece ter falado assaz claramente sobre esta matéria, mas favorece muito a esta opinião, pois quando distingue a beatitude do homem, distingue duas, uma natural, outra sobrenatural." 74 Por outro lado, Suarez e seus seguidores também não podem negar qualquer desejo de ver a Deus. Como diz Lubac, fazê-lo

seria rejeitar de modo bem manifesto uma tradição há muito tempo unânime. Contudo, o desejo admitido difere totalmente do da tradição. Não poderia tratar-se, explicam, senão de um desejo puramente elícito e condicionado, de um certo desejo imperfeito, análogo a um vago agrado. É uma "veleidade", é um anseio (souhait), como vem espontaneamente ao espírito a propósito de todos os tipos de coisas impossíveis, e aliás sem interesse essencial... Desejo incapaz de engendrar uma verdadeira

72 SUAREZ, 1856, p. 145.

73 Ibidem, p. 153.

74 Ibidem, p. 152. Ver também o comentário de Laporta (1965, p. 20). 
"inquietude" quanto a seu objeto, o qual, no estado natural, a supor que este pudesse ser conhecido, seria visto como pura quimera. ${ }^{75}$

Desse modo, Suarez aparenta fazer uma reconciliação com a tradição quando, na verdade, rompe com ela, e assim pavimenta um caminho novo para o tomismo. Segundo Lubac, "doravante existe uma corrente tomista, uma escola tomista, para professar, contrariamente a S. Tomás, que a natureza racional é um todo fechado no qual tendências e capacidades ativas se correspondem rigorosamente". ${ }^{76}$

O famoso Jansenius, cuja influência posterior dispensa apresentações, pode ser visto, sob alguns aspectos, como seguidor de Baius, mas as diferenças são importantes. Ambos partem de uma visão bastante otimista do estado adâmico, que acaba resultando em uma visão assaz pessimista da condição atual do homem. No entanto, Jansenius está melhor resguardado que Baius de aproximações com Pelágio a respeito da natureza íntegra. Para o autor, a justiça original não era natural ao primeiro homem como a saúde é para o animal. Trata-se não de um elemento constitutivo da natureza humana, mas de um dom acrescido a ela sem ser-lhe devido. "O magnífico 'equilíbrio' da condição primeira não era obtido sem uma graça suficiente. Enquanto Baius, mesmo falando de graça, confessava que era em um sentido impróprio, Jansenius precisa que se deve entendê-la de uma 'verdadeira graça', de uma 'graça sobrenatural'."'77

Apesar de sobrenatural e necessária a Adão para que este fizesse o bem, a graça suficiente era apenas um instrumento a ser usado pelo livre-arbítrio, de modo que este último mantinha-se como a causa principal da boa ação; relação que se inverterá após o pecado, quando a vontade cativa não terá méritos. É de notar que, embora Jansenius garanta que a vontade adâmica era indiferente ao bem e ao mal, e por isso teria guardado os méritos de manter-se no estado de natureza íntegra, diz também que, sem a graça, o livre-arbítrio bastaria somente para o mal. É nessa ambigüidade que Lubac se baseia para afirmar que, como em Baius, Jansenius traria um "naturalismo" latente a sua apresentação do estado de natureza íntegra:

Sem dúvida, insiste ele ainda, a graça não era devida aos méritos de Adão, e a glória final não estava mais ao alcance dos esforços naturais; mas uma e outra não eram contudo postuladas por exigências essenciais? Ele está bem perto de o afirmar 
quando, após ter dito que Deus deve a si mesmo conceder seu socorro ao ser que acaba de criar, assinala como razão disso menos a sublimidade do fim a que Deus o destina do que a fraqueza da criatura que, tirada do nada, conserva sempre um pendor ao nada. ${ }^{78}$

Como em Agostinho e Tomás, a beatitude do homem janseniano se encontra em Deus. Nesse sentido, ele tende naturalmente a Deus. O amor a Deus, entretanto, é sobrenatural no sentido de depender de um socorro sobrenatural. A idéia de dívida não surge em função da necessidade de completar uma noção que, sem o auxílio, sequer seria uma natureza. Ao contrário, se há dívida, não é para com a criatura, que não tem direitos, mas para com a bondade e justiça do criador, que sem dar a graça não poderia condenar os homens inocentes que se afastassem dele. Estes, na verdade, estariam cumprindo uma tendência natural de toda criatura:

É uma ordem da Natureza e da Providência divina que tudo o que é segue as leis delas e, encerrado nos limites delas, retorna a sua origem por um movimento perpétuo... Pois é daí que vem este grande peso que arrasta todas as criaturas para a destruição de seu ser e que as faria cair no abismo do nada se elas não fossem sustentadas pela palavra que sustenta todo o Universo. E esta inclinação geral é como um traço marcado pela mão da Natureza, que faz ver a todos os que têm olhos suficientemente bons para reconhecê-lo qual é a origem de todas as coisas criadas. ${ }^{79}$

Mesmo Adão e os anjos tendiam ao nada de onde haviam saído mais do que a Deus, onde se encontra sua beatitude. Por isso caíram:

É o que fez com que os anjos e o primeiro homem não tenham permanecido na glória em que Deus os havia posto no início; mas, tendo-se achado como em um país estrangeiro, abandonaram Deus e caíram para baixo como para sua pátria natural; e teriam passado até o nada se Deus não os tivesse segurado na queda por uma bondade onipotente. ${ }^{80}$

O nada é a pátria natural da criatura, enquanto Deus é o país estrangeiro. Como criatura, o homem tendia ao nada, mas foi posto, de maneira sobrenatural, ou mesmo antinatural, em uma posição de felicidade extrema, sem carências, junto de sua finalidade última, Deus. Ora, foi essa beatitude, a qual é o fim último do homem em toda a tradição já examinada, que precipitou o movimento de desagregação: 
Esta união e esta inteligência produziam uma alegria e um prazer inefáveis em seu espírito, devido à posse de um tão grande bem, e o vigor da imortalidade em seu corpo; e estas duas graças supremas conservavam uma profunda paz nas duas partes de que ele era composto; davam a seu espírito o meio de seguir Deus sem nenhuma resistência e a seu corpo de seguir seu espírito sem dificuldade.

Não lhe faltava nada de tudo o que ele podia desejar e possuir legitimamente e não havia nada que pudesse abalar sua felicidade interior e exterior; entretanto ele ainda não estava firme neste estado por aquela última firmeza que lhe teria feito amar esta sabedoria divina a ponto de esquecer-se a si mesmo, de esquecer sua própria grandeza comparando-a com a grandeza infinita. De modo que, tendo começado a perceber sua felicidade e a reconhecer qual era, foi arrebatado e seduzido por sua própria beleza; começou a olhar-se com prazer e por este olhar que o transformou no objeto de seus próprios olhos e desviou sua visão de Deus para voltá-la inteira para si mesmo, caiu na desobediência. ${ }^{81}$

A felicidade adâmica não se sustentou porque o homem não estava pronto para perder-se na felicidade divina, renunciando à sua própria natureza. Buscando fazer de si uma natureza autônoma, cuja realização maior seria uma felicidade causada por si mesmo, o homem perdeu a felicidade sobrenatural que a graça suficiente lhe propiciava, caindo no único movimento próprio da natureza criada, o movimento para o nada. Por isso, por ser esse o seu movimento natural, após o pecado o homem só pode ser salvo por uma graça eficaz, que, ao libertar a vontade, determina-a. Sem essa violência antinatural, a desagregação prevalece:

De modo que assim como as árvores dobradas com grande esforço recolocam-se com tanto mais violência em seu estado natural, tão logo a mão que as retinha deixa-as ir; do mesmo modo, em sentido contrário, desde que a natureza humana foi corrompida, e como que entortada pelo pecado, ela não pode mais ser reendireitada senão por uma força extrema; e assim que é deixada a si mesma e abandonada, precipita-se por seu próprio peso no vício de sua origem. ${ }^{82}$

Nesse quadro fica difícil ver como o pensamento de Jansenius possa esconder, ainda que latente (como crê Lubac), um naturalismo similar ao de Baius. O que ocorre, aparentemente, é uma ruptura com o conceito tradicional de natureza, na medida em que a plena realização da criatura depende de uma intervenção sobrenatural que não satisfaz as carências puramente naturais, mas sobrepõe-se à natureza. 


\section{A natureza humana em Pascal}

É no contexto jansenista que se desenvolve o pensamento de Pascal, o qual, em meados do século XVII, escreve à sombra da ainda poderosa idéia de pura natureza. Os defensores dela partem daqueles elementos (substância, dinamismo interno e finalidade) já presentes na concepção aristotélica de natureza para então constituir uma idéia de natureza que, deixando à parte a beatitude sobrenatural cristã, se vincula indissoluvelmente às noções de completude e suficiência, ou seja, à condição de um ser que tem em si seu princípio e o poder de alcançar seu fim. Após vermos as críticas de Jansenius, seria de crer que Pascal renunciaria ao uso do termo natureza (pelo menos fora do estado adâmico), mas não é isso que ocorre. Como explicá-lo?

A partir do que foi visto até agora, não é difícil imaginar por que a aplicação do termo natureza ao homem pascaliano sofre de sérias dificuldades. Um elemento fundamental do campo semântico desse termo é, como vimos longamente, a substancialidade. Em alguns textos, é nesse sentido que Pascal usa o termo para o homem, sob nítida inspiração da união substancial cartesiana: Fr. 72/199: “(...) nós somos compostos por duas naturezas antagônicas e de gêneros diversos, alma e corpo". ${ }^{83}$ Será, então, que Pascal encontra no eu, como Descartes, uma substância pensante?

Vejamos o que nosso filósofo diz a respeito: no Fr. 455/597, Pascal mostra a inutilidade do esforço daqueles que, como Miton, tentam afastar o aspecto odioso do eu humano. Isso ocorre porque este não é um aspecto, mas $\mathbf{0}$ aspecto característico do eu. A aparência agradável não pode ter outro efeito além de ser uma cortina de fumaça, $F r$. 455/597: "Vós Miton, vós o cobris, não o tirais por isso, continuais portanto sendo odioso". ${ }^{84} \mathrm{O}$ eu não é odioso apenas relativamente, enquanto causa de desprazer para os outros sujeitos. Nesse nível mais superficial, a amabilidade seria um remédio eficiente. Contudo, o eu é odioso na sua realidade própria, ele é injusto em si.

No segundo parágrafo desse fragmento, Pascal explicita os dois níveis do sujeito: "Numa palavra, o eu tem duas qualidades: é injusto em si, fazendo-se centro de tudo; é incômodo aos outros, querendo sujeitá-los, pois cada eu é o inimigo e desejaria ser o tirano de todos os outros." ${ }^{85}$ A máscara de gentileza que esconde o desprazer relativo nada pode contra o desprazer em si do eu,

83 As citações dos Pensamentos de Pascal serão feitas a partir da tradução de Sérgio Milliet, para o volume Pascal, da coleção Os Pensadores, São Paulo, Abril Cultural, 1979. O primeiro algarismo corresponde à numeração Brunschvicg, usada por Sérgio Milliet, o segundo à numeração Lafuma, hoje mais difundida entre os especialistas. Devido a esses índices, dispensar-nos-emos de dar o número da página.

84 PASCAL (1979).

85 Idem. 
sua causa. Ou melhor, o incômodo do eu, disfarçável, é menos grave que aquilo que o provoca: o fato de o eu se fazer centro de tudo. $\mathrm{O}$ egocentrismo e o amor próprio constituem tão intrinsecamente o eu que não podem mais ser excluídos.

Partindo do pressuposto pascaliano de que todo homem busca a felicidade, talvez possamos esclarecer as razões desse ódio. Se o homem faz uma coisa é porque lhe parece que isso o fará feliz. $\mathrm{O}$ mundo material não basta, porém, para saciar sua sede de bens. É preciso que ele domine seus iguais e, ainda assim, não se satisfará, sendo obrigado a tiranizar cada vez mais os outros. Essa insatisfação, dado fundamental do homem pascaliano, é razão da incomodidade que o eu produz. Mas por que é insaciável?

A verdade que abre este mistério é que Deus criou o Homem com dois amores, um por Deus, outro por si mesmo; mas com esta lei, que o amor por Deus seria infinito, isto é, sem nenhum outro fim além de Deus mesmo, e que o amor por si mesmo seria finito, ligando-se a Deus. (...) O pecado tendo chegado, o homem perdeu o primeiro destes amores; e o amor por si ficou nesta grande alma capaz de um amor infinito; este amor próprio se estendeu e inundou o vazio deixado pelo amor de Deus; e assim ele se amou por si e todas as coisas por si, isto é, infinitamente. ${ }^{86}$

A expressão "eu odioso" representa o homem que não enxerga quão insuperável é sua pequenez. Ele pensa que pode, reunindo o mundo finito em torno de si, sanar sua carência inconsciente de infinitude. A descontinuidade entre o finito e o infinito não permite, porém, que a carne preencha um espaço que só Deus pode ocupar. Assim, a concupiscência se ilude com sua capacidade e tenta tiranizar os outros, sem contudo remediar a angústia humana.

$\mathrm{O}$ amor-próprio desmedido (devido ao deslocamento do centro para a concupiscência, o transitório) fez que o homem mentisse, se mascarasse e se revestisse de qualidades ilusórias para obter poder e estima. Sua essência verdadeira, o que há de infinito no ser humano, lhe foi tirada através de Adão. Agora só existe enquanto ausência incompreensível.

As qualidades maléficas dominam, portanto, a natureza atual do homem e é por isso que a amabilidade não pode destruir o eu odioso. Se lhe tirarmos o que tem de odioso, nada restará. Ele é injusto em si, tirano por natureza e inimigo de todos. Contudo, Pascal não chega a formular o eu como uma substância cuja natureza é ser injusta. O caráter insuperável da injustiça do eu não faz dela um atributo essencial, pois continua sendo uma qualidade 
negativa. Portanto, o que há de mais palpável no eu é negatividade extrema, sem consistência ontológica.

Tendo-se afastado de Deus, ou seja, de si mesma, de sua essência, a substância do homem se pulverizou em inúmeras qualidades passageiras, incapazes por si mesmas de se reconstituírem como acidentes de uma substância. Fr. 323/688:

Que é o eu? Um homem que se põe à janela para ver os passantes, se eu estiver passando, posso dizer que se pôs à janela para ver-me? Não, pois não pensa em mim em particular. Quem gosta de uma pessoa por causa de sua beleza, gostará dela? Não, pois a varíola, que tirará a beleza sem matar a pessoa, fará que não goste mais dela; e, quando se gosta de mim por meu juízo ou por minha memória, gosta-se de mim? Não; pois posso perder essas qualidades sem me perder. Onde está pois esse eu, se não se encontra no corpo nem na alma? E como amar o corpo ou a alma, senão por essas qualidades, que não são o que faz o eu, de vez que são perecíveis? Com efeito, amaríamos a substância da alma de uma pessoa abstratamente, e algumas qualidades que nela existissem? Isso não é possível, e seria injusto. Portanto, não amamos nunca a pessoa, mas somente as qualidades. ${ }^{87}$

A natureza humana se reduz então a uma sucessão de estados desligados entre si: Fr. 109/638:

Quando nos sentimos bem dispostos, mal sabemos como faríamos se estivéssemos doentes; quando ficamos doentes, tomamos o remédio de bom grado: o mal nos convence a fazê-lo. Não temos mais paixões nem desejos de divertimentos e passeios, que a saúde nos dava e que são incompatíveis com as necessidades da doença. A natureza proporciona então paixões e desejos de conformidade com o estado presente... ${ }^{88}$

Da mesma forma, a idéia de corpo também perde o valor de ordenação e unidade e reduz-se a uma denominação convencional. Substância corpórea? Pascal responde com ironia: Fr. 115/65:

(...) Um homem é uma substância; mas, se o anatomizarmos, será ele a cabeça, o coração, as veias, o estômago, cada veia, cada porção de veia, o sangue, cada humor do sangue? Uma cidade, um campo, de longe, são uma cidade e um campo; mas, à medida que nos aproximamos, são casas, árvores, telhados, folhas, plantas, formigas, pernas de formigas, até o infinito. Tudo isso se inclui na palavra campo. ${ }^{89}$ 
A corrupção decorrente do pecado original implodiu a substância humana. Em Pascal, ontologia e ética se encontram para fazer a desgraça (ou a salvação) do homem. No paraíso, Adão vivia em comunhão com Deus, uma união perfeita onde a participação na essência divina garantia a congregação dos acidentes humanos. O pecado destruiu essa ordenação. Embora faça parte do universo ético, a ação pecaminosa teve conseqüências metafísicas. A punição do homem foi o afastamento de Deus, da sua verdadeira essência, aquilo que há de mais profundo no homem ("mais eu do que eu mesmo"): Fr 555/929:

Não te compares aos outros, mas a mim. Se não me encontras naqueles a quem te comparas, tu te comparas a um abominável. Se me encontras neles, tu te comparas a mim. Mas o que há de comparar? Tu? Ou eu em ti? Se é a ti que comparas, comparas um abominável. Se sou eu, então, comparas-me comigo mesmo. Ora, eu sou Deus em tudo. ${ }^{90}$

Assim sendo, dado o pecado, em que sentido se pode ainda falar de natureza humana?

A palavra natureza, ou a variação luz natural, também aparece na epistemologia pascaliana. O método de conhecimento absolutamente racional exigiria que todas as proposições e todos os termos fossem definidos. Entretanto, isso não passa de um ideal impossível, já que implicaria uma regressão ao infinito. Descartado esse método, devido a nossa finitude, Pascal propõe um sucedâneo:

Pois há um, e é o da geometria, que é em verdade inferior por ser menos convincente, mas não menos certo. Ele não define tudo nem prova tudo, e esta é sua falha; mas ele não supõe senão coisas claras e constantes para a luz natural, e é por isso que ele é perfeitamente verdadeiro, sendo sustentado pela natureza quando o discurso não o pode (grifos nossos). ${ }^{91}$

Pascal acredita na validade desse método, mas ao mesmo tempo conhece sua fragilidade. O sentimento do coração que garante os primeiros princípios é facilmente confundido com a imaginação, potência enganadora, e nada impede que o hábito consolide princípios falsos. Diz o autor: Fr. 92/125: "Que são nossos princípios naturais senão princípios de hábito?"92 Sem o auxílio da graça divina, é apenas o hábito que garante a força das verdades básicas da ciência, e esta "natureza" que as sustenta pode muito bem ser apenas hábito. 
Fr. 233/418: "Nossa alma é lançada no corpo, onde encontra número, tempo, dimensões. Raciocina sobre isso e a isso chama natureza, necessidade, e não pode crer em outra coisa." ${ }^{93}$

Pascal aponta que a força dos céticos está na impossibilidade de provar esses princípios e no desconhecimento de nossa origem. Como não sabemos se fomos criados por um Deus enganador, nada garante nosso sentimento natural. A força dos dogmáticos está em que essa dúvida é artificial, ou mesmo metódica (no sentido cartesiano), mas não sincera. Em nossa vida real, não nos é possível questionar os princípios, pois o coração, instrumento da natureza, nos impede: Fr. 282/110:

Sabemos que não sonhamos; por maior que seja a nossa impotência em prová-lo pela razão, essa impotência mostra-nos apenas a fraqueza da nossa razão, mas não a incerteza de todos os nossos conhecimentos, como pretendem. Pois o conhecimento dos princípios, como o da existência de espaço, tempo, movimento, números, é tão firme como nenhum dos que nos proporcionam os nossos raciocínios. E sobre esses conhecimentos do coração e do instinto é que a razão deve apoiar-se e basear todo o seu discurso. ${ }^{94}$

Todavia, essa vitória dos dogmáticos só mostra que a razão reluta em destruir a si mesma. É verdade que Pascal destaca a humilhação da razão ao ver-se submetida a algo externo a ela, o coração, mas, no fim das contas, é a uma exigência racional que o coração atende ao sentir os princípios. A incapacidade da razão, limitada a raciocinar, leva a natureza a buscar algo outro que garanta o funcionamento pleno da própria razão, humilhada sim, morta não. A natureza que atua agora é a totalidade do universo racional. Este só se sustenta tendo princípios como ponto de partida. Se se abrisse para o infinito através das definições infindáveis do método ideal, a razão implodiria a si mesma e se decretaria inútil. Se isso ocorresse, a existência do ser humano caminharia para o insuportável e, ainda mais, sem possibilidades de compreender sua situação. Por isso, o hábito, vilão do conhecimento, tornase necessário. "Renversement du pour au contre." A natureza é aqui aquilo que impõe as condições de possibilidade do trabalho racional, as quais em si mesmas não devem ser questionadas. O sábio, porém, nunca é alheio a esse processo. Fr. 93/126: “(...) O hábito é uma segunda natureza que destrói a primeira. Mas que é a natureza? Por que não é o hábito natural? Receio muito que essa natureza não seja ela própria senão um primeiro hábito, assim como o 
hábito uma segunda natureza." 95 Assim como as definições da geometria, nada impede que os hábitos se sucedam ao infinito e que não haja uma natureza original. Mais uma vez, portanto, o ser humano se acha perdido e o conceito de natureza, a rigor, se mostra dificilmente aplicável ao homem.

Sempre, porém, que o ceticismo parece prestes a triunfar, a natureza reage e o dogmatismo sobrevive, mesmo acima da capacidade racional de argumentar. Os argumentos dos erros dos sentidos, a impossibilidade de distinção racional entre o sono e a vigília, e mesmo a hipótese de que nossos princípios sejam meramente habituais, nada disso elimina a força dos dogmáticos. De fato, sinceramente, continuamos sem poder duvidar de tudo, sem poder duvidar que estamos despertos, sem poder duvidar que duvidamos, logo nunca houve um pirronismo perfeito. Tal adversário, o pirrônico perfeito, certamente venceria os dogmáticos apontando nossa incapacidade de provar a boa origem de nossa natureza. Mas apenas hipoteticamente "venceria", porque tal adversário não existe de fato. A razão confunde os dogmáticos e a natureza confunde os pirrônicos.

Como seria bom e coerente suspender o juízo e não optar entre esses dois caminhos! Infelizmente, porém, não há essa possibilidade: Fr. 434/131: “(...) Eis aberta entre os homens a guerra em que todos devem tomar partido, enfileirando-se, necessariamente, ou no dogmatismo ou no pirronismo; pois quem pensar em permanecer neutro será pirrônico por excelência. Essa neutralidade é a essência da cabala pirrônica: quem não é contra eles é excelentemente por eles.... ${ }^{96}$ Pascal nos põe aqui numa situação similar à da Aposta. Lá também, diante da impossibilidade de assentir ou recusar fundamentadamente à proposição "Deus existe", a suspensão do juízo se apresentava tentadora. No entanto, suspender o juízo seria viver como se Deus não existisse, de modo que a escolha estaria já consumada. Em nosso caso ocorre o mesmo: o homem deve escolher entre ceticismo e dogmatismo. A razão, que também é parte da natureza, nos obriga a ceder aos argumentos céticos. A natureza, a mesma que garante os princípios dos quais a razão depende, nos impede. A suspensão do juízo, por sua vez, representa já assumir uma posição cética. Não podemos evitar um dos dois caminhos, nem subsistir em nenhum deles. Mergulhado no paradoxo, o que resta ao homem?

Perdido entre essas duas seitas, ele é obrigado a submeter-se a uma hipótese externa à racionalidade, mas que a razão, mesmo em choque, percebe ser a única capaz de explicar sua situação miserável. Não se trata, é bom 
destacar, de uma saída do paradoxo (o dilema persiste) mas da busca de tornar a situação do homem compreensível: Fr. 434/131:

(...) se o homem nunca tivesse sido corrompido, gozaria com segurança, em sua inocência, tanto da verdade quanto da felicidade. E se o homem só tivesse sido corrompido, não teria qualquer idéia da verdade ou da beatitude. Mas, infelizes que somos, e mais do que se não houvesse grandeza em nossa condição, temos uma idéia da felicidade, e não podemos alcançá-la; sentimos uma imagem da verdade e só possuímos a mentira: somos incapazes de ignorar em absoluto e de saber com certeza, de tal maneira é manifesto que estivemos num grau de perfeição de que infelizmente caímos! ${ }^{17}$

É neste ponto que vemos como, para Pascal, o reencontro do conceito de natureza se faz enquanto exigência de totalidade. Como diz Magnard,

invencivelmente hipostasiamos nossos conceitos, para ver neles a expressão de realidades que transcendem a experiência. $\mathrm{O}$ fato de estas realidades não existirem nos autoriza a negar aos conceitos o valor objetivo, não toda a significação. O homem pode não realizar ele próprio uma natureza, não constatar ordem no mundo nem sentido na história; estas não são simples negações, mas privações, que não deixam de constituir problema. A intemperança metafísica de que o homem é prova não é o estigma de um desequilíbrio, uma ausência? ${ }^{98}$

Se Pascal, junto com Jansenius, combate os defensores da pura natureza, não pode, por outro lado, ser insensível ao modelo de completude natural delimitado por esses teóricos. A diferença é que Pascal, como bom agostiniano, não admite ver a beatitude como um acréscimo desnecessário à natureza: a união com Deus é a única fonte de satisfação. Logo, deve haver, como apontam aqueles teóricos, uma natureza proporcionada a tal fim. Se não há tal proporção, nem por isso teríamos de concluir ou bem por uma dívida do criador (como Baius), ou bem pela existência de um fim puramente humano (como os defensores da pura natureza). Ao contrário, a desproporção aponta para a idéia de decadência. Mas aqui protestará o leitor: não há novidade pois toda a tradição teológica lida com o conceito de queda. É verdade, mas, de um lado, escapou a boa parte da tradição o alcance e o peso metafísico da queda, os quais Pascal experimenta de maneira radical; de outro, é preciso lembrar que Pascal não busca, como a tradição, suprimir o paradoxo. Por isso, nosso filósofo vê na decadência do homem um poder explicativo diverso do que viam seus antecessores. O homem é rei destronado, por isso sua situação é tão 
insuportável, diferentemente, por exemplo, de todos os animais: Fr. 409/117: "A grandeza do homem é tão visível que se tira mesmo de sua miséria. Porque ao que é natureza nos animais nós chamamos miséria no homem; por onde reconhecemos que, como a natureza é hoje semelhante à dos animais, ele caiu de uma natureza melhor, que lhe era própria." 99

O homem está perdido em agitações e divertimentos fúteis e não pode evitar fazê-lo devido à corrupção de sua natureza, mas tem um instinto secreto, resto da primeira natureza, que o faz conhecer que a felicidade está no repouso. Esse repouso pode ser lido como o reencontro da totalidade, da verdadeira natureza. Desse modo, a idéia de natureza não apenas faz a crítica da situação do homem como aponta para uma exigência radical da felicidade.

O repouso só virá quando a capacidade do homem para o infinito for preenchida novamente, ou seja, quando o homem se reunir a Deus. O pecado foi uma tentativa de o homem constituir-se em totalidade própria, abandonando seu verdadeiro centro, que é Deus. Isso subverteu totalmente os valores do homem e o levou a vagar às cegas pelo mundo, perdendo-se em coisas materiais enquanto o soberano bem se afastava. Mas, apesar de tudo, o vazio deixado por Deus no homem é algo muito mais real e presente que todo o resto, e é por isso que a natureza, enquanto exigência de totalidade, continua apontando para o infinito. Fr. 415/127: "A natureza do homem considera-se de duas maneiras: uma segundo seu fim, e então é incomparável; outra segundo a multidão, como se julga a natureza do cavalo e do cão, ao ver sua corrida e seu animum arcendi; e então o homem é abjeto e vil..." ${ }^{100}$ Não é difícil ver nesse fragmento uma retomada da discussão teológica do fim último do homem. Diria Tomás que o fim é sobrenatural quanto à consecução (dada a desproporcionalidade dos meios humanos), mas natural quanto ao apetite, o que sinaliza a grandeza do homem. Suarez mostrou a fragilidade dessa solução e exilou a visão beatífica na pura sobrenaturalidade. Pascal, por sua vez, mergulha no paradoxo, vendo na elevação do fim e na precariedade dos meios manifestações da mesma natureza irrealizável do homem, simultaneamente signo de grandeza e miséria. Os animais são felizes, satisfeitos consigo mesmos, sua natureza não demanda mais do que a animalidade pode fornecer. Já para o homem, reduzir-se à animalidade é o desespero total. O desejo de ser feliz, próprio de toda criatura, fica sem princípios adequados e oscila de um bem para outro, incapaz de se satisfazer. A natureza pede muito mais do que a ordem das coisas pode dar. 
Tal irrealização é vivida como carência, uma carência absoluta, por ser a privação de Deus, e tanto mais opressiva por ser tudo que restou de uma natureza que um dia teve um substrato metafísico e o perdeu. Por outro lado, como imagem de Deus, a natureza humana exige por si mesma o sobrenatural para reconstituir-se como totalidade. A situação miserável conjugada à impossibilidade interna de recuperação aponta para a necessidade de o homem superar o próprio homem, apelando para a ordem da caridade, já que as ordens das matérias e dos espíritos se mostraram incapazes de reconfortá-lo.

Por fim, o que há de mais paradoxal na idéia de natureza humana em Pascal é que ela atua como a exigência radical de uma realização que, de certo modo, a suprime. Como diz Magnard, "não há natureza própria ao homem; o pecado foi ter querido ter uma; esta pretensão verificou-se decepcionante; a salvação estará apenas na renúncia total a si". ${ }^{101}$ Assim como a razão se submete diante do incompreensível quando julga racionalmente necessário, também a natureza humana aceitará suprimir sua auto-suficiência (a qual já foi perdida pelo pecado), quando vir que não pode satisfazer suas próprias exigências. Não se tratará, então, como bem observou Magnard, de recuperar um estado de pura natureza, mas de colocar-se nos braços do infinito, aceitando ser membro de um todo que a supera.

Embora pouco adequada à nossa condição atual (desagregação) e à dos bem-aventurados (adesão a Deus), a idéia de natureza humana permanece como um valor essencial para o pensamento pascaliano. Ela funciona como um referencial para julgar nossa condição, referencial que não teria a mesma força se Pascal não tivesse conhecido o combate aos defensores da pura natureza. Como idéia reguladora, ela denuncia a incompletude e aponta para a recuperação. Em outras palavras, a natureza é o conceito que, por meio da idéia de carência, faz a ponte entre a miséria humana e o anseio pela graça divina.

\section{Referências Bibliográficas}

AGOSTINHO, S. Confissões. São Paulo: Paulus, 1984.

BAC, 1971.

Do Livre Arbítrio. In: AGOSTINHO. Obras de San Agustin (III). Madrid:

AGostinho, S. A natureza e a graça. In: AGOSTINHO. A Graça (I). São Paulo: Paulus, 1999. . A vida feliz. São Paulo: Paulinas, 1993. 
ARISTÓTELES. Categorias. In: ARISTÓTELES. Organon. Lisboa: Guimarães, 1985.

Physique. Paris: Les Belles Lettres, 1961.

GILSON, E. Introduction à l'etude de Saint Augustin. Paris: Vrin, 1987.

JANSENIUS, C. Discours de la reformation de l'homme intérieur. Paris: [s.n.], 1644.

LAPORTA, J. La destinée de la nature humaine selon Thomas d'Aquin. Paris: Vrin, 1965.

LEOPOLDO E SILVA, F. A inquietude no livro I das Confissões. Não publicado.

LUBAC, H. Augustinisme et Théologie Moderne. Paris: Aubier, 1965.

MAGNARD, P. Valeur critique et euristique de l'idée de nature chez Pascal. In:

COMUNICATIONS AU COLLOQUE DES AMIS DE PORT ROYAL, Clermond Ferrand. Anais...: Clemond Ferrand: [s. n.], 1962.

MERLIN. N. Saint Augustin et les dogmes de la grâce et du péché originel. Paris: Letouzey, 1931.

PASCAL, B. Euvres complètes. Paris: Seuil, 1963.

. Pensamentos. In: PASCAL, B. Pascal. São Paulo: Abril Cultural, 1979.

(Coleção Os Pensadores).

. Lettre sur la mort de son père. In: PASCAL, B. Oeuvres Complètes. Paris:

Seuil, 1963.

SUAREZ, Francisci R. P. De Gratia. In: SUAREZ, F. Opera Omnia. Paris: Ludovicum Vivès, Bibliopolam Editorem, 1857. v. 7.

SUAREZ, F. De Ultimo Fine hominis. In: SUAREZ, F. Opera Omnia. Paris: Ludovicum Vivès, Bibliopolam Editorem, 1856. v. 4.

TOCANNE, B. L'idée de nature en France dans la seconde moitié du XVII siècle. Paris: Klincksieck, 1978

TOMÁS, S. Suma contra os Gentios. Porto Alegre: Edipucrs, 1996. 